
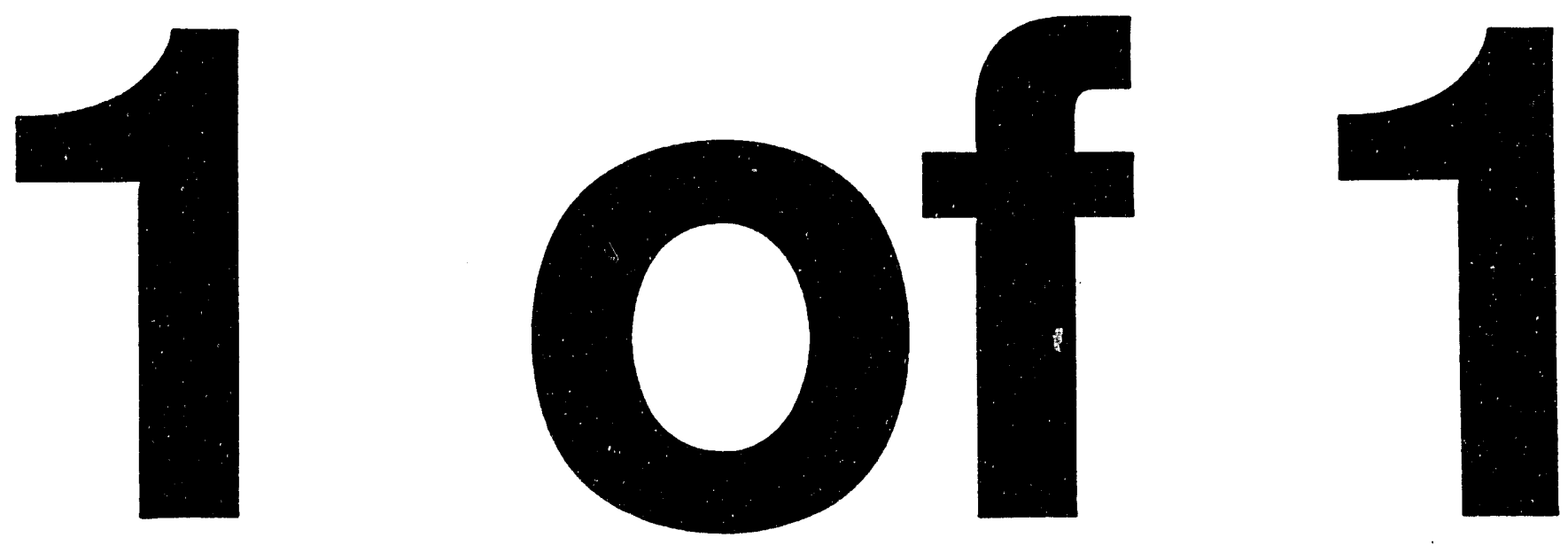


\section{UMTRA PROJECT WATER SAMPLING AND ANALYSIS PLAN}

\section{BELFIELD AND BOWMAN, NORTH DAKOTA}

August 1994

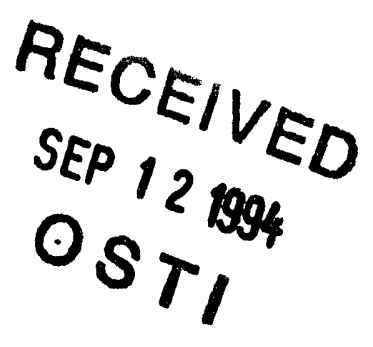


This report has been reproduced from the best available copy. Available in paper copy and microfiche.

Number of pages in this report: 44

DOE and DOE contractors can obtain copies of this report from:

Office of Scientific and Technical Information

P.O. Box 62

Oak Ridge, TN 37831

(615) 576-8401

This report is publicly available from:

National Technical Information Service

Department of Commerce

5285 Port Royal Road

Springfield, VA 22161

(703) $487-4650$ 


\title{
UMTRA PROJECT \\ WATER SAMPLING AND ANALYSIS PLAN \\ BELFIELD AND BOWMAN, NORTH DAKOTA
}

August 1994

\author{
Prepared for \\ U.S. Department of Energy \\ UMTRA Project Office \\ Albuquerque, New Mexico \\ Prepared by \\ Jacobs Engineering Group Inc. \\ Albuquerque, New Mexico
}

\section{DISCLAIMER}

\begin{abstract}
This report was prepared as an account of work sponsored by an agency of the United States Government. Neither the United States Government nor any agency thereof, nor any of their employees, makes any warranty, express or implied, or assumes any legal liability or responsibility for the accuracy, completeness, or usefulness of any information, apparatus, product, or process disclosed, or represents that its use would not infringe privately owned rights. Reference herein to any specific commercial product, process, or service by trade name, trademark, manufacturer, or otherwise does not necessarily constitute or imply its endorsement, recommendation, or favoring by the United States Government or any agency thereof. The views and opinions of authors expressed herein do not necessarily state or reflect those of the United States Government or any agency thereof.
\end{abstract}




\section{EXECUTIVE SUMMARY}

Surface remedial action is scheduled to begin at the Belfield and Bowman Uranium Mill Tailings Remedial Action (UMTRA) Project sites in the spring of 1996. Water sampling was conducted in 1993 at both the Belfield processing site (BEL-01) and the Bowman processing/disposal site (BOW-01). Results of the sampling at both sites indicate that ground water conditions have remained relatively stable over time.

Water sampling activities are not scheduled for 1994 because ground water conditions at the two sites are relatively stable, the 1993 sampling was comprehensive, and surface remediation activities are not scheduled to start until 1996. The next water sampling event is scheduled before the start of remedial activities and will include sampling selected monitor wells at both sites and several domestic wells in the vicinity. 


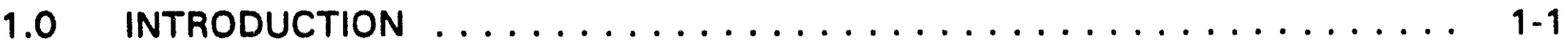

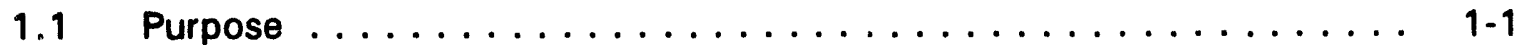

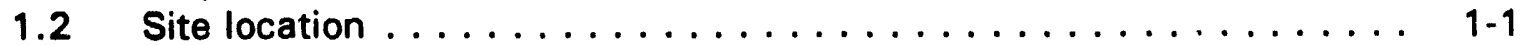

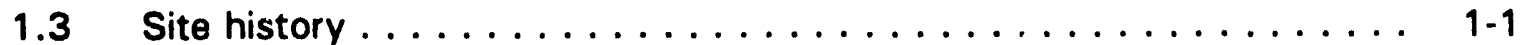

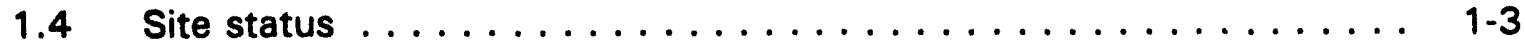

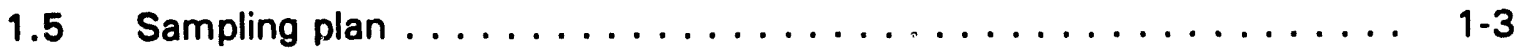

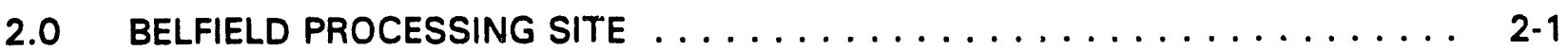

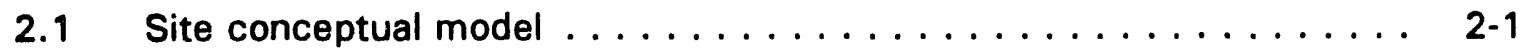

2.1 .1 Physiographic setting .................. 2-1

2.1 .2 Geology ........................ 2-1

2.1.3 Hydrology ..................... 2-1

2.1 .4 Water quality .................... 2-5

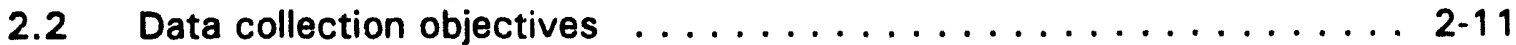

2.2.1 Regulatory requirements ............... 2-11

2.2.2 Compliance monitoring ................ 2-11

2.2.3 Site characterization .................. 2-11

2.2.4 Risk assessment ................... 2-13

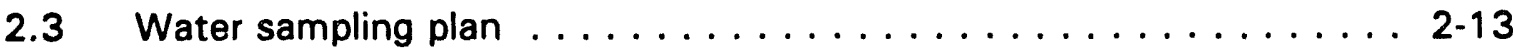

3.0 BOWMAN PROCESSING/DISPOSAL SITE $\ldots \ldots \ldots \ldots \ldots \ldots \ldots \ldots \ldots \ldots$

3.1 Site conceptual model .................... 3-1

3.1.1 Physiographic setting ................ 3-1

3.1.2 Geology ...................... 3-1

3.1.3 Hydrology ...................... 3-1

3.1.4 Water quality ..................... 3-8

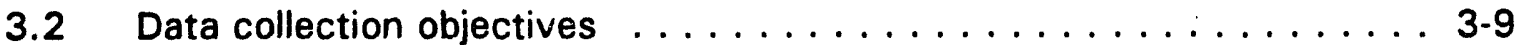

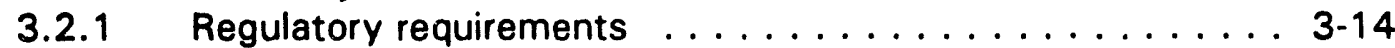

3.2.2 Compliance monitoring $\ldots \ldots \ldots \ldots \ldots$ 3-14

3.2.3 Site characterization . . . . . . . . . . . . . . 3-14

3.2.4 Risk assessment . . . . . . . . . . . . . . . . . 3-14

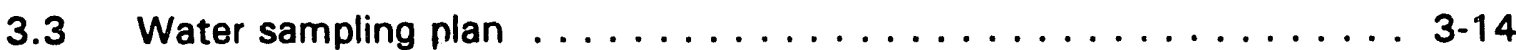

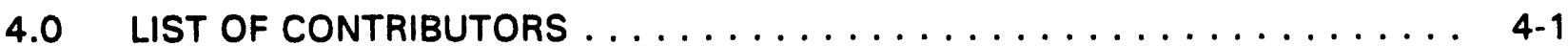

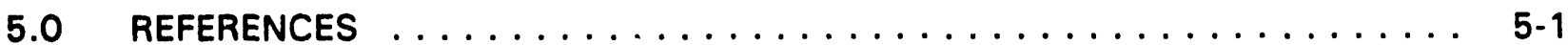




\section{LIST OF FIGURES}

\section{Figure}

Page

1.1 Locations of the Belfield and Bowman sites, North Dakota . . . . . . . . . . . 1-2

2.1 Location of monitor wells at the Belfield processing site, North Dakota . . . . 2-2

2.2 Hydrogeologic cross section of the Belfield processing site, North Dakota . . . 2-4

2.3 Potentiometric surface of the upper zone at the Belfield processing site, North Dakota . . . . . . . . . . . . . . . . . . . . . . . . . . 2 2-6

2.4 Potentiometric surface of the lignite zone at the Belfield processing site, North Dakota . . . . . . . . . . . . . . . . . . . . . . . . . 2-7

2.5 Uranium concentrations versus time at the Belfield processing site, North Dakota . . . . . . . . . . . . . . . . . . . . . . . 2-10

3.1 Location of monitor wells at the Bowman processing site, North Dakota . . . 3-2

3.2 Hydrogeologic cross section of the Bowman processing site, North Dakota . . 3-4

3.3 Potentiometric surface of the upper zone at the Bowman processing site, North Dakota . . . . . . . . . . . . . . . . . . . . . . 3-6

3.4 Potentiometric surface of the lignite zone at the Bowman processing site, North Dakota . . . . . . . . . . . . . . . . . . . . . . . 3-7

3.5 Uranium distribution in the uppermost aquifer at the Bowman processing site, North Dakota . . . . . . . . . . . . . . . . . . . . . . . . . . . 3-11

3.6 Uranium concentrations versus time at the Bowman processing site, North Dakota . . . . . . . . . . . . . . . . . . . . . . . . . . 3-12 


\section{LIST OF TABLES}

Table

Page

2.1 Monitor well information for the Belfield processing site, North Dakota . . . . 2-3

2.2 Summary of ground water quality in the upper zone at the Belfield processing site, North Dakota . . . . . . . . . . . . . . . . . . . . . . . . . . 2-9

2.3 Summary of ground water quality in the li: unite zone at the Belfield processing site, North Dakota . . . . . . . . . . . . . . . . . 2-12

3.1 Monitor well information for the Bowman processing site, North Dakota . . . 3-3

3.2 Summary of ground water quality in the upper zone at the Bowman processing site, North Dakota . . . . . . . . . . . . . . . . . . 3-10

3.3 Summary of ground water quality in the lignite zone at the Bowman processing site, North Dakota . . . . . . . . . . . . . . . . . . 3-13 


\section{Acronym Definition}

$\begin{array}{ll}\text { ac } & \text { acre } \\ \mathrm{cm} / \mathrm{s} & \text { centimeters per second } \\ \text { DOE } & \text { U.S. Department of Energy } \\ \text { DQO } & \text { data quality objective } \\ \text { EPA } & \text { U.S. Environmental Protection Agency } \\ \mathrm{ft} & \text { foot } \\ \mathrm{ft} / \mathrm{day} & \text { feet per day } \\ \mathrm{ft} / \mathrm{mi} & \text { feet per mile } \\ \mathrm{ha} & \text { hectare } \\ \mathrm{km} & \text { kilometer } \\ \mathrm{m} & \text { meter } \\ \mathrm{m} / \mathrm{km} & \text { meters per kilometer } \\ \mathrm{MCL} & \text { maximum concentration limit } \\ \mathrm{mg} / \mathrm{L} & \text { milligrams per liter } \\ \mathrm{mi} & \text { mile } \\ \mathrm{pCi} / \mathrm{L} & \text { picocuries per liter } \\ \text { QA } & \text { quality assurance } \\ \text { QAIP } & \text { quality assurance implementation plan } \\ \text { OC } & \text { quality control } \\ \text { SOP } & \text { standard operating procedure } \\ \text { UMTRA } & \text { Uranium Mill Tailings Remedial Action } \\ \text { WSAP } & \text { water sampling and analysis plan }\end{array}$




\subsection{INTRODUCTION}

\subsection{PURPOSE}

This water sampling and analysis plan (WSAP) provides the regulatory and technical basis for ground water and surface water sampling at the Belfield processing site (BEL-01) and the Bowman processing/disposal site (BOW-01) in North Dakota. It identifies and justifies the sampling locations, analytical parameters, and sampling frequencies. The ground water data are used for site characterization, risk assessment, and compliance monitoring.

Ground water and surface water monitoring activities are based on the U.S. Environmental Protection Agency (EPA) regulations in 40 CFR Part 192 (1994) and the proposed EPA standards of 1987 (52 FR 36000 (1987)), Uranium Mill Tailings Remedial Action (UMTRA) Project standard operating procedures (SOP) (JEG, n.d.), the Technical Approach Document (DOE, 1989), the Guidance for Implementing the UMTRA Project Long-term Surveillance Program (DOE, 1992), and the most effective technical approach for each site.

This WSAP summarizes the results of previous water sampling activities and the plan for water sampling activities for calendar year 1994.

\subsection{SITE LOCATION}

The Belfield processing site is in Stark County, North Dakota, approximately 1 mile (mi) (1.6 kilometers [km]) southeast of the town of Belfield (Figure 1.1). The 10.7-acre (ac) (4.3-hectare [ha]) tract is in Section 4, Township 139 North, Range 99 West, Fifth Principal Meridian. The site is bordered by the Burlington Northern Railroad tracks on the south and by the North Branch of the Heart River on the north.

The Bowman processing/disposal site is in Bowman County, North Dakota, approximately $7 \mathrm{mi}(11 \mathrm{~km})$ west of the town of Bowman (Figure 1.1). The 12.1 ac (4.9 ha) tract is in Section 34, Township 132 North, Range 103 West, Fifth Principal Meridian. The site is bordered by the Burlington Northern Railroad tracks on the north and by cultivated fields and pasture lands on the east, south, and west. U.S. Highway 12 is 400 feet (ft) (122 meters [m]) south of the site. The Bowman site is 65 road mi $(105 \mathrm{~km})$ from the Belfield site.

\subsection{SITE HISTORY}

Rotary kilns were operated at both the Belfield and Bowman processing sites for the combustion of uraniferous lignite. Soil contamination resulted from particulate air emissions and lignite storage. Uranium mill tailings were not generated and tailings piles do not exist at the sites. Union Carbide processed lignite at the Belfield site from 1964 to 1966, shipping the ash to its ore processing plant in Rifle, Colorado. Kerr-McGee processed lignite at the 


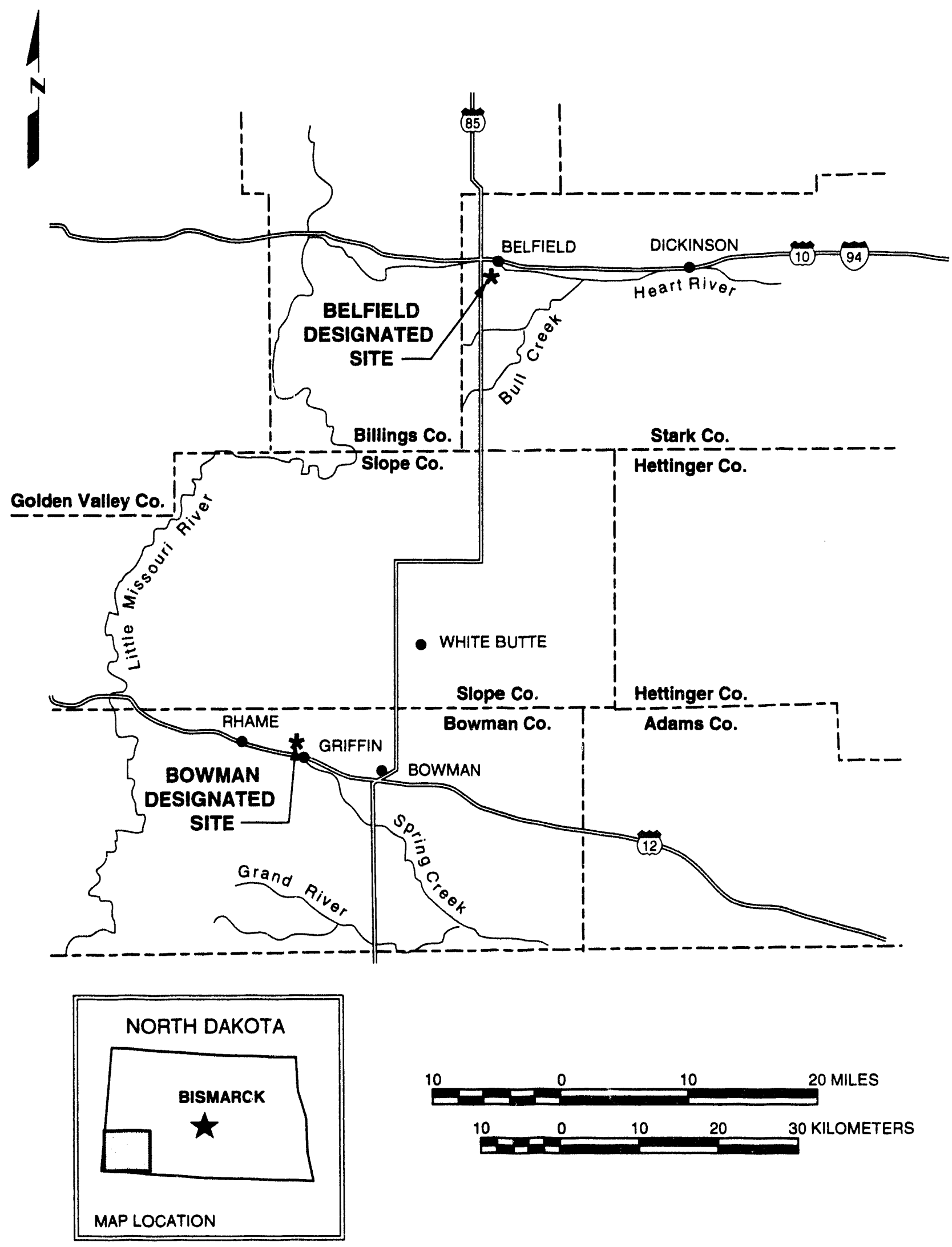

FIGURE 1.1

LOCATIONS OF THE BELFIELD AND BOWMAN SITES, NORTH DAKOTA 
Bowman site from 1964 to 1967, shipping ash to its ore processing plant at Ambrosia Lake, New Mexico.

\subsection{SITE STATUS}

Remedial action activities at the Belfield and Bowman sites are scheduled to begin during 1996. In the disposal option proposed for the sites, contaminated materials at the Bowman site will be consolidated and contaminated materials from the Belfield processing site will be relocated to the Bowman processing/disposal site for codisposal.

\subsection{SAMPLING PLAN}

Ground water samples were collected from U.S. Department of Energy (DOE) monitor wells and domestic wells at the Belfield and Bowman sites in August and July 1993, respectively. Analytical results indicate the ground water quality is relatively stable at the two sites.

Water sampling is not scheduled for 1994 because ground water conditions at the two sites are relatively stable, the 1993 sampling was comprehensive, and surface remediation activities are not scheduled to start until 1996. Water sampling is scheduled prior to start of remedial activities and will include sampling selected monitor wells at both sites and several domestic wells in the vicinity. 


\title{
2.0 BELFIELD PROCESSING SITE
}

2.1

\author{
SITE CONCEPTUAL MODEL
}

The conceptual site model is based on available hydrogeologic information, water quality data, site reconnaissance, and data from monitor wells installed in the saturated units beneath the site (Figure 2.1 and Table 2.1). The conceptual site model is discussed below.

\subsubsection{Physiographic setting}

The Belfield site is in the Missouri Plateau of the northern Great Plains physiographic province. The region is drained by the Missouri River, which flows east through the center of the Williston Basin. The terrain in site vicinity consists of gently rolling grassland.

\subsubsection{Geology}

The Belfield processing site is underlain by sediments of the Sentinel Butte Formation, the uppermost unit of the Tertiary Fort Union Group. The Sentinel Butte Formation consists of approximately $150 \mathrm{ft}(45 \mathrm{~m})$ of interbedded sandstones, siltstones, claystones, and lignites, with varying amounts of carbonaceous material. The formation dips eastward at approximately 12 feet per mile (ft/mi) $(2.5$ meters per kilometer $[\mathrm{m} / \mathrm{km}])$. Lithologic logs from the monitor wells at the Belfield processing site indicate that a $60-\mathrm{ft}(18-\mathrm{m})$ interbedded sequence of silty sancistone, sandy claystone, and silty claystone underlies a thin soil cover (Figures 2.1 and 2.2). This hy Jrogeologic unit is called the upper zone of fine-grained sediments. The upper zone is underlain by a lignite unit approximately $15 \mathrm{ft}(4.5 \mathrm{~m})$ thick. This hydrogeologic unit is called the lignite zone. The lignite zone is underlain by claystone of undetermined thickness.

\subsubsection{Hydrology}

Ground water at the Belfield processing site occurs in fine-grained sediments and fractured lignites under unconfined and semiconfined conditions, with water levels ranging from 15 to $38 \mathrm{ft}(4.6$ to $11.6 \mathrm{~m})$ below the ground surface. The ground water system in the vicinity of the site is recharged directly by precipitation and seepage from intermittent streams and standing surface water. There is no evidence of ground water discharge to the land surface or to surface water in the site vicinity. Seasonal fluctuations of the potentiometric surfaces of the upper zone and the lignite zone are generally less than $2.5 \mathrm{ft}(0.8 \mathrm{~m})$ (from lowest to highest ground water elevation). These water levels fluctuate in response to spring snowmelt and periods of maximum precipitation in the summer and fall. 


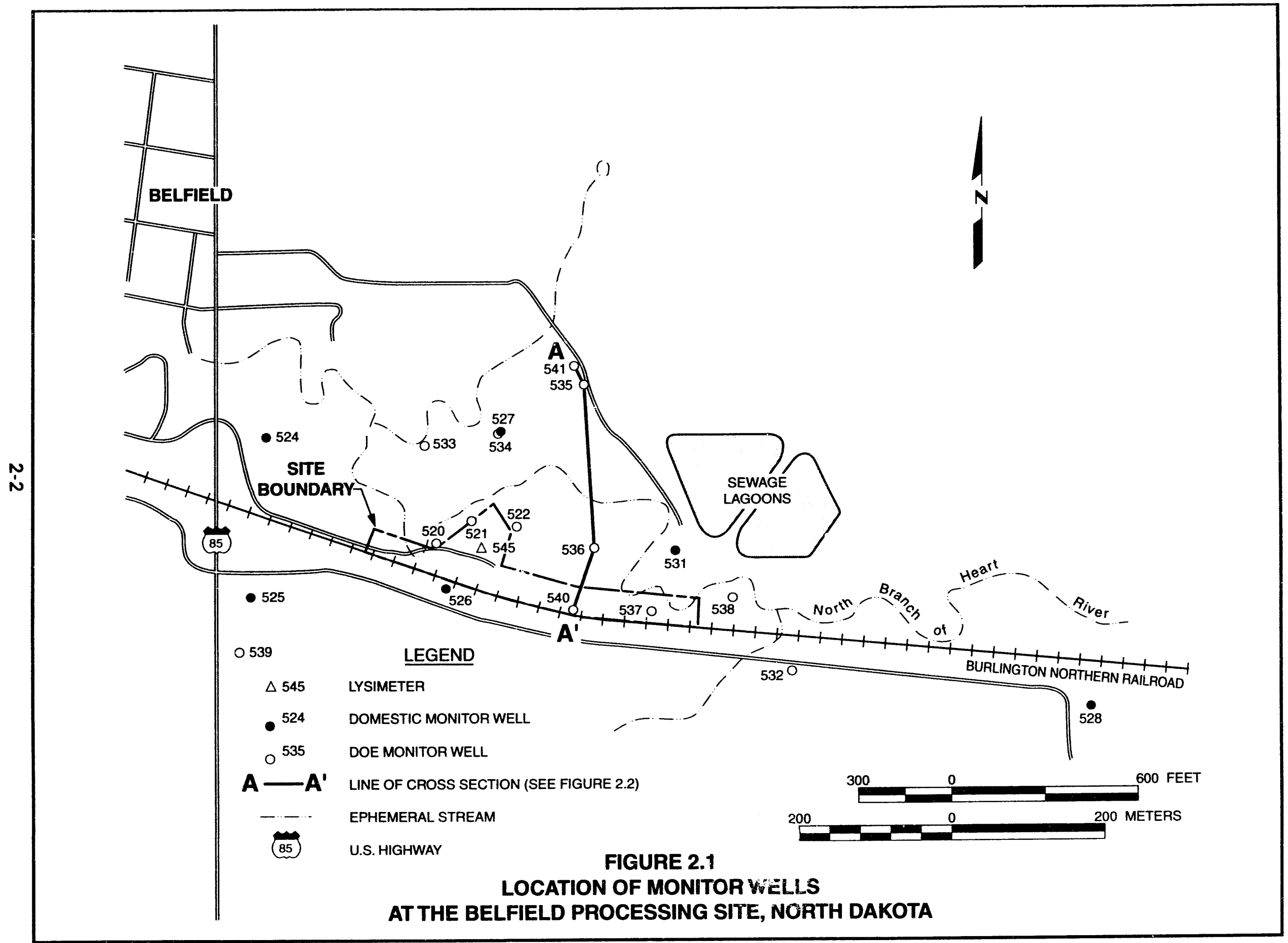


Table 2.1 Monitor well information for the Belfield processing site, North Dakota

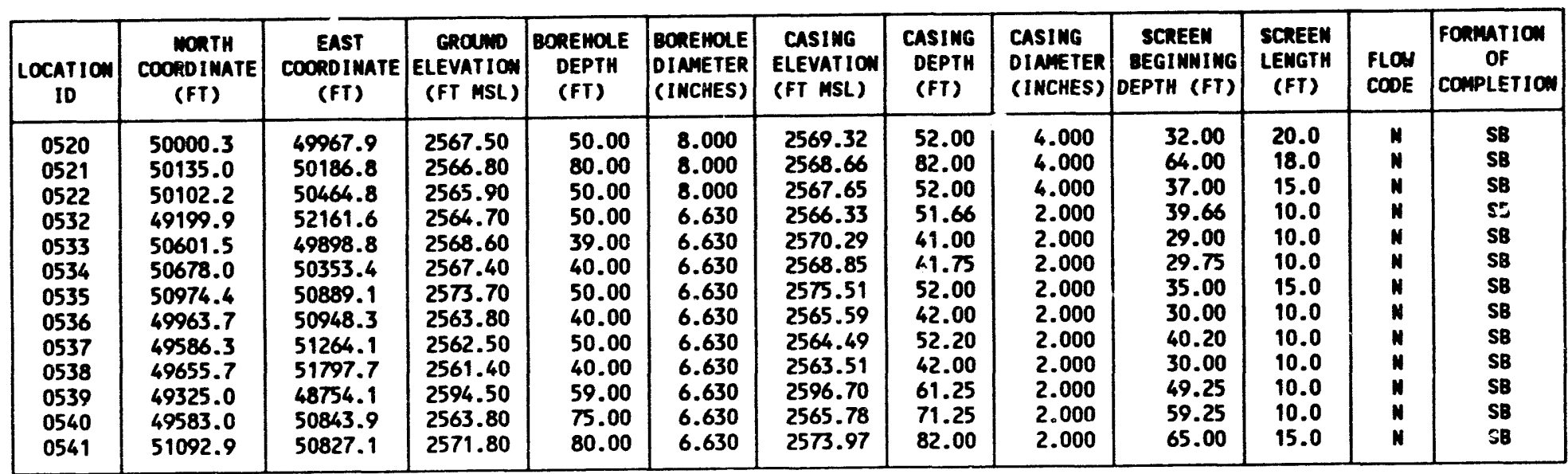

FORMATION OF COMPLETION COOE:

FLON RELATIONSHIP CODE:

SB - SENTINEL BUTTE FORMATION 


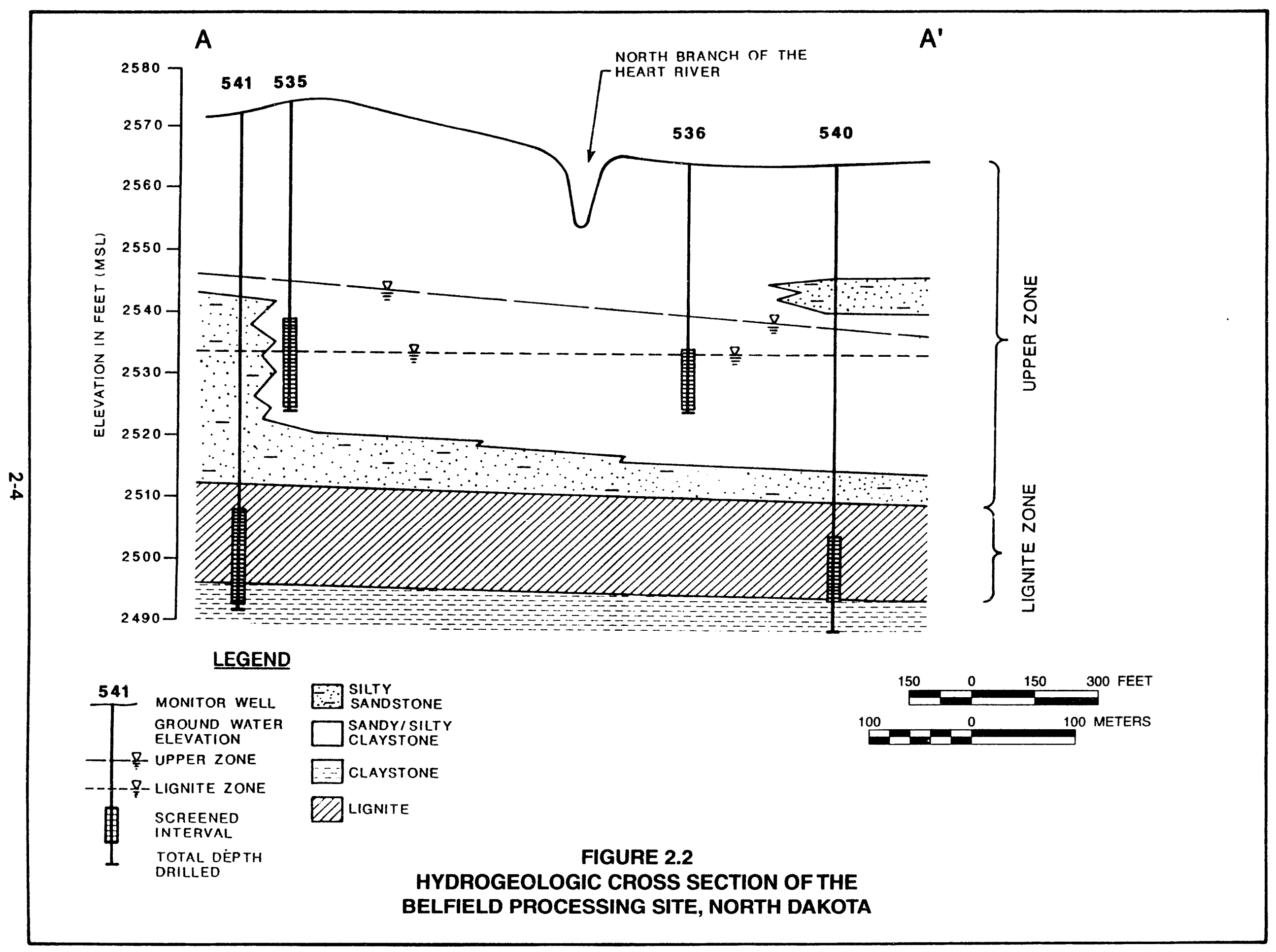


Ground water in this area generally flows east. The potentiometric surface in the upper zone beneath the Belfield site indicates ground water flows generally south and southeast with a hydraulic gradient averaging 0.02 (Figure 2.3).

Minor variations in the potentiometric surface may be caused by surface water infiltration from the North Branch of the Heart River, seepage from the sewage lagoons northeast of the site, and lateral and vertical lithological differences. The potentiometric surface in the lignite zone beneath the Belfield site indicates ground water generally flows east with a hydraulic gradient averaging 0.0004 (Figure 2.4). The hydraulic gradient observed in the lignite zone is low because of the topographic relief in the area and the relatively higher transmissivity in the fractured lignite.

To determine the vertical hydraulic gradient, ground water elevations were compared in adjacent monitor wells screened in the upper zone and the lignite zone. Ground water elevations were higher in the upper zone, indicating a downward hydraulic gradient.

Slug tests were conducted in monitor wells to measure the hydraulic conductivities of both hydrogeologic units in the Belfield site vicinity. The average hydraulic conductivity of the upper zone was estimated to be 0.7 feet per day (ft/day) $\left(2.5 \times 10^{-4}\right.$ centimeters per second $\left.[\mathrm{cm} / \mathrm{s}]\right)$. The average hydraulic conductivity of the fractured lignite zone was estimated to be $2.6 \mathrm{ft} /$ day $\left(9.2 \times 10^{-4} \mathrm{~cm} / \mathrm{s}\right)$. An aquifer pumping test conducted in monitor well BEL-01-0521 in the lignite zone shows hydraulic conductivity was $34 \mathrm{ft} /$ day $\left(1.2 \times 10^{-2} \mathrm{~cm} / \mathrm{s}\right)$.

Based on an average hydraulic conductivity of $0.7 \mathrm{ft} /$ day $\left(2.5 \times 10^{-4} \mathrm{~cm} / \mathrm{s}\right)$, an average hydraulic gradient of 0.02 , and an estimated effective porosity of 0.20 , the average linear ground water velocity for the upper zone was $0.07 \mathrm{ft} / \mathrm{day}$ $\left(2.5 \times 10^{-5} \mathrm{~cm} / \mathrm{s}\right)$. Based on an average hydraulic conductivity of $34 \mathrm{ft} / \mathrm{day}$ $\left(1.2 \times 10^{-2} \mathrm{~cm} / \mathrm{s}\right)$, an average hydraulic gradient of 0.0004 , and an estimated effective porosity of 0.05 , the average linear ground water velocity for the lignite zone was $0.27 \mathrm{ft} /$ day $\left(9.6 \times 10^{-5} \mathrm{~cm} / \mathrm{s}\right)$.

\subsubsection{Water quality}

Water quality sampling was conducted at the Belfield site from 1986 to 1988 and again in 1993. A comprehensive list of constituents was analyzed during screening monitoring to determine background and baseline ground water quality in the zones of interest beneath the site. This list was modified during subsequent sampling events to focus on the following constituents related to uranium processing activities and with standard field and geochemical parameters: ammonium, antimony, arsenic, cadmium, calcium, chromium, chloride, gross alpha, iron, lead, magnesium, manganese, molybdenum, nitrate, potassium, radium-226 and -228 , selenium, sodium, sulfate, total dissolved solids, total organic carbon, uranium, and vanadium. 


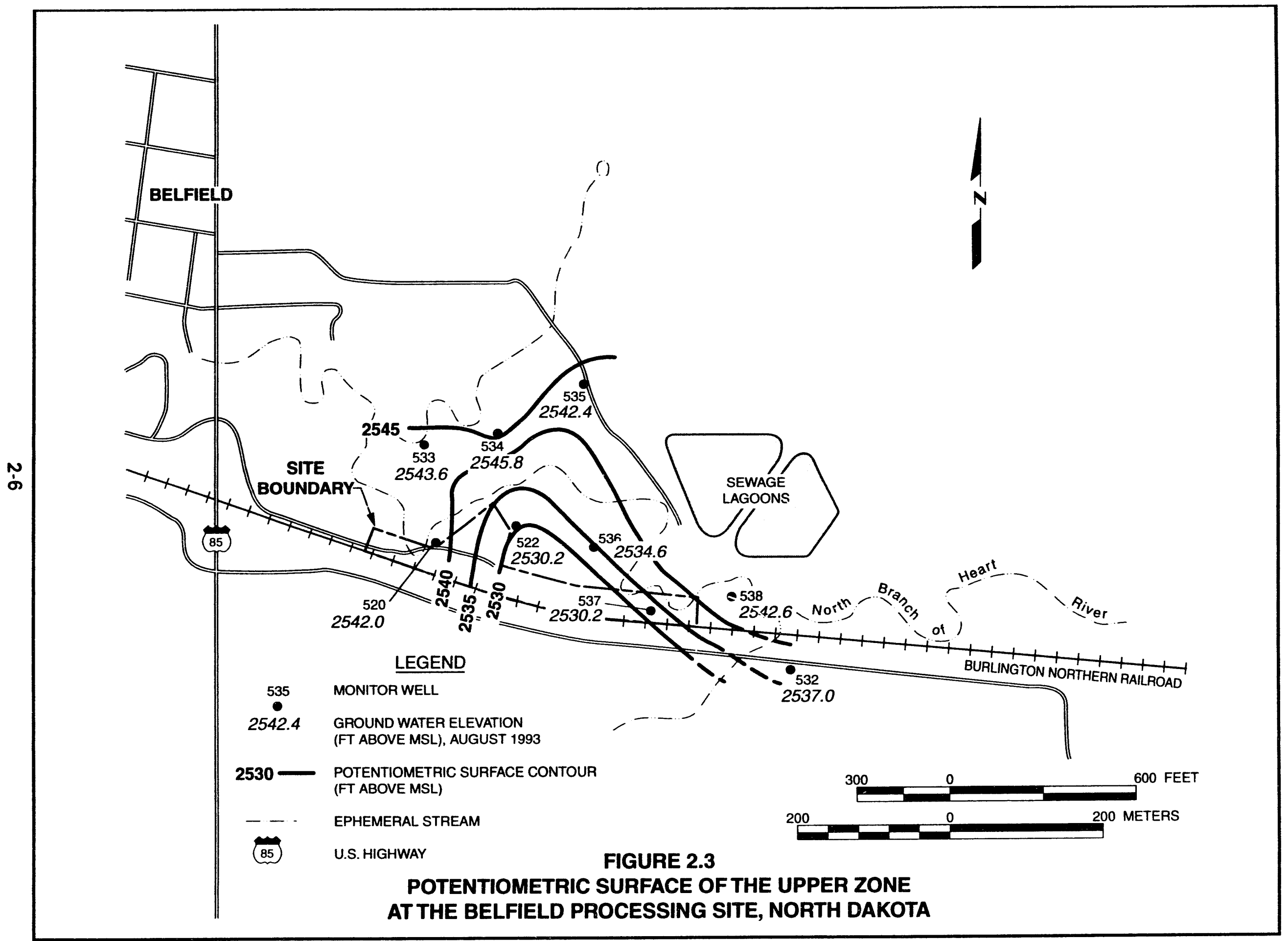




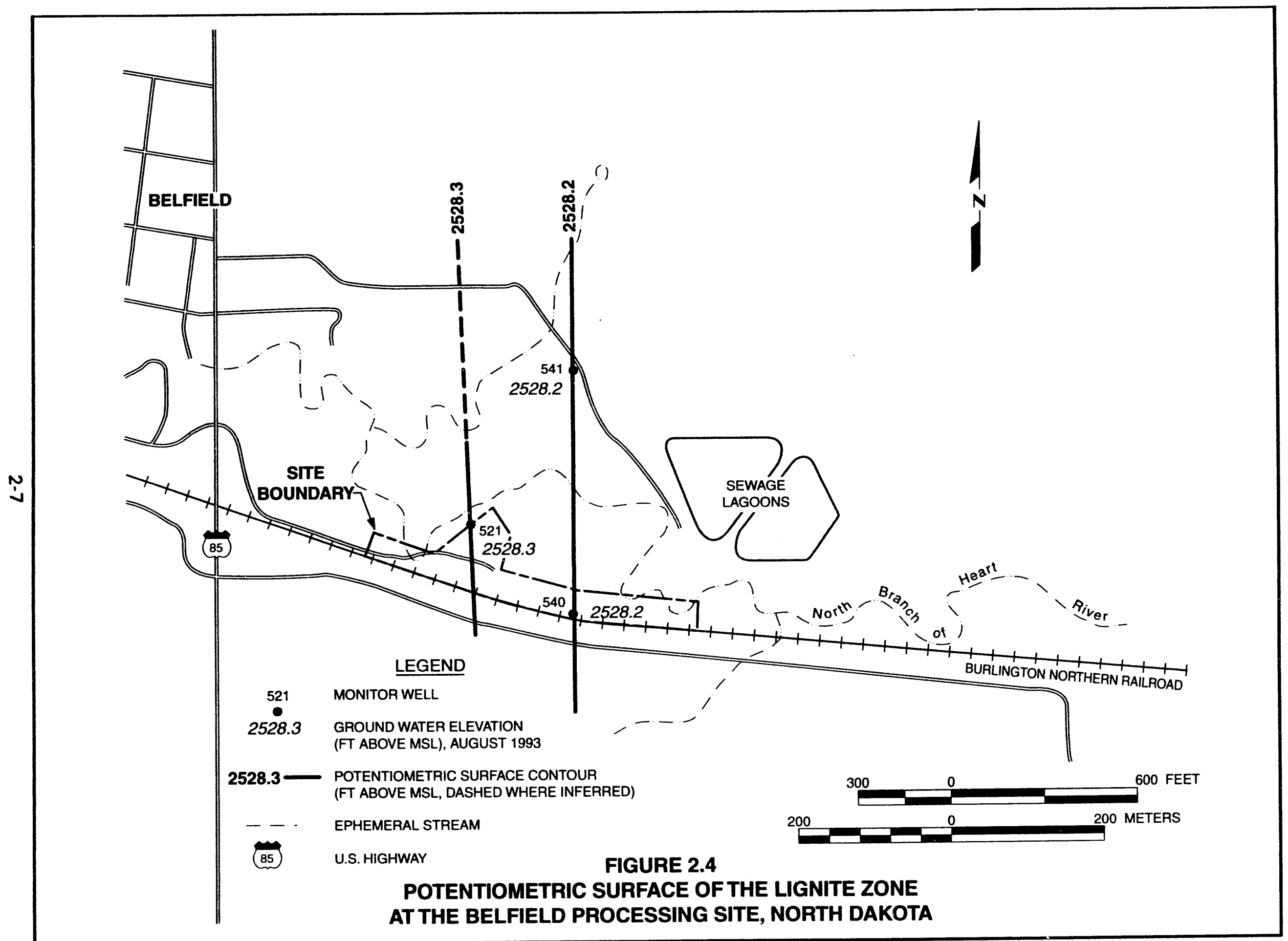




\section{Background ground water quality}

Background ground water quality in the upper zone was determined by analyzing samples collected from monitor wells BEL-01-0533, -0534, and -0535 upgradient from the site (Figure 2.1). Background ground water quality data from these monitor wells show that maximum concentrations of cadmium, chromium, lead, molybdenum, selenium, and uranium, and activities of net gross alpha exceeded the proposed EPA maximum concentration limits (MCL). Similar concentrations of some of these constituents were also observed in an off-site domestic well. Background ground water quality in the lignite zone was evaluated in samples from monitor well BEL-01-0541. Concentrations of constituents of concern in ground water generally were lower in the lignite zone than in the upper zone.

\section{Extent of existing ground water contamination}

Union Carbide operated an ashing plant to process uraniferous lignite at the Beltield site from 1964 to 1966 . The processing operation consisted of drying and burning lignite in a rotary kiln. This operation involved only combustion of organic material. No chemical, metallurgical, or nuclear processes were involved. Airborne contamination was minimal because of the completely enclosed ashing circuit and the scrubber system on the stack. Ash from the kiln was air-cooled in a rotary cooler, loaded into railroad cars, and shipped to the Union Carbide uranium ore processing plant in Rifle, Colorado. Sources of soil and ground water contamination at the Belfield processing site resulting from the lignite processing operations include water seepage from lignite stockpiled before ashing operations, ash and dust released to the atmosphere during the process, and sludges and residues from the stack gas-scrubber. Surface water runoff from the site may have transported suspended and dissolved contaminants into the North Branch of the Heart River.

Contaminant concentrations in the soil pore fluid were analyzed in a sample collected from a suction lysimeter (BEL-01-0545) on the processing site $20 \mathrm{ft}$ $(6 \mathrm{~m})$ below the ground surface (Figure 2.1). Chromium, molybdenum, nitrate, selenium, and uranium concentrations exceeded the proposed EPA MCLs in the lysimeter samples. With the exception of nitrate, some of these contaminants in the unsaturated zone may be a result of the lignite ashing process. Nitrate concentrations are not thought to be related to uranium processing activities.

Ground water samples collected from on-site and downgradient monitor wells at the Belfield site were analyzed to determine the extent and magnitude of ground water contamination related to uranium processing activities. Ground water quality from monitor well BEL-01-0520 is thought to represent the maximum of site-related contamination in the upper zone. In this zone, average chromium, molybdenum, selenium, and uranium concentrations and net gross alpha activities exceeded the proposed EPA MCLs (Table 2.2). However, only uranium concentrations were elevated above background levels (Figure 2.5). Contaminants detected that exceed background concentrations in ground water 
Table 2.2 Summary of ground water quality in the upper zone at the Belfield processing site, North Dakota

\begin{tabular}{|c|c|c|c|}
\hline & & Background ${ }^{\star}$ & On-site/downgradient ${ }^{b}$ \\
\hline Constituent & $\mathrm{MCL}^{\mathrm{C}}$ & \multicolumn{2}{|c|}{ (Median values) } \\
\hline Ammonium & & 0.54 & 0.45 \\
\hline Antimony & & 0.027 & 0.009 \\
\hline Arsenic & 0.05 & 0.005 & 0.005 \\
\hline Cadmium & 0.01 & 0.003 & 0.002 \\
\hline Calcium & & 46.1 & 41.4 \\
\hline Chloride & & 4.9 & 10.2 \\
\hline Chromium & 0.05 & 0.017 & $0.015^{d}$ \\
\hline Iron & & 0.07 & C. 1 \\
\hline Lead & 0.05 & 0.027 & 0.019 \\
\hline Magnesium & & 44.3 & 29.1 \\
\hline Manganese & & 0.19 & 0.20 \\
\hline Molybdenum & 0.10 & 0.05 & $0.06^{d}$ \\
\hline Net gross alpha & 15.00 & $13.80^{d}$ & $11.93^{d}$ \\
\hline Nitrate & 44.0 & 1.0 & 1.0 \\
\hline Potassium & & 7.89 & 5.68 \\
\hline Radium $(-226$ and -228$)$ & 5.00 & 0.37 & 0.62 \\
\hline Selenium & 0.01 & $0.021^{d}$ & $0.006^{d}$ \\
\hline Sodium & & 1103.8 & 340.1 \\
\hline Sulfate & & 1667 & 609 \\
\hline Uranium & 0.044 & $0.014^{d}$ & $0.008^{d}$ \\
\hline Vanadium & & 0.01 & 0.02 \\
\hline Total dissolved solids & & 3520 & 1646 \\
\hline pH & & 7.59 & 7.04 \\
\hline
\end{tabular}

aBackground monitor wells: BEL-01-0533, -0534, -0535, and -0539 .

bOn-site/downgradient monitor wells: BEL-01-0520, -0522, -0532, -0536, -0537, and -0538 .

${ }^{c}$ Concentrations in milligrams per liter; activities of net gruss alpha and radium in picocuries per liter.

Maximum value exceeds maximum concentration limit. 


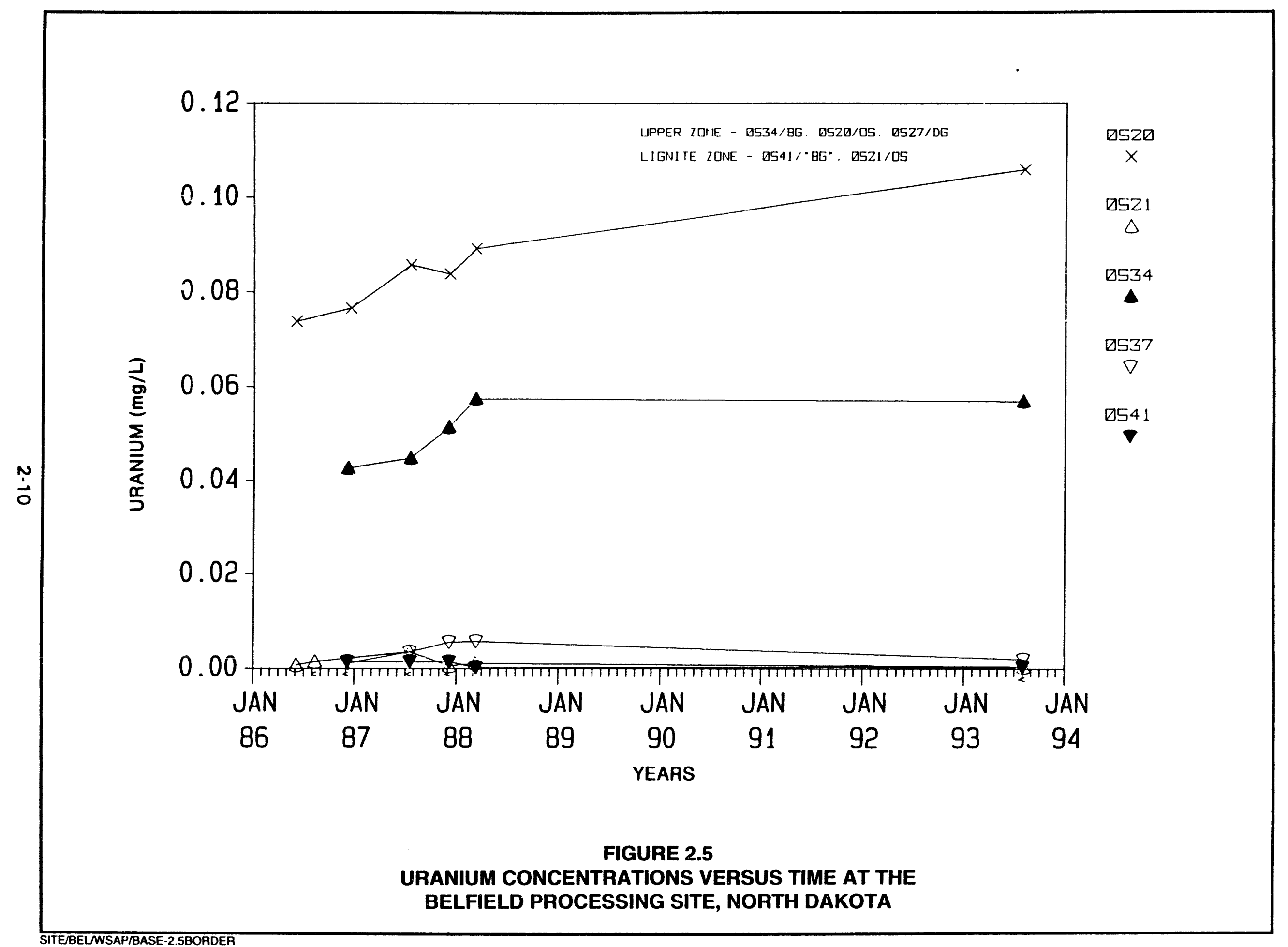


do not form a discrete plume in the upper zone downgradient from the processing site. In the lignite zone, the average selenium concentrations in ground water exceeded the proposed EPA MCL (Table 2.3). Because background selenium levels in ground water also exceeded the $\mathrm{MCL}$, elevated selenium concentrations apparently occur naturally in the area.

Some constituents of concern (such as antimony, chromium, lead, molybdenum, selenium, uranium, and vanadium) occur at naturally elevated concentrations in shallow ground water adjacent to lignite zones in this region of North Dakota. This has made it difficult to distinguish between the potential extent and impact of ground water contamination related to former uranium processing activities at this site and the impact of naturally occurring concentrations of these constituents on the environment. Furthermore, farm wastes, septic tanks, sewage disposal ponds, and wastes from current industrial activities on the site may contribute some contaminants present in ground water in the site vicinity.

\subsection{DATA COLLECTION OBJECTIVES}

Data collection objectives identify the reasons for collecting data, which are regulatory requirements, compliance monitoring, site characterization, risk assessment, and oth er considerations.

Data quality objectivis (DOO) define the manner in which samples are collected, handled, and analyzed. DOOs also define analytical support levels; follow standard procedures for water sampling, preservation, transport, and various other field procedures; ensure procedures follow quality assurance (QA) and quality control $(\mathrm{OC})$ protocols; and provide analytical data validation. DQOs for data collection and evaluation activities are listed in the WSAP guidance document (DOE, 1993), the quality assurance implementation plan (QAIP) (DOE, 1994), and applicable SOPs (JEG, n.d.).

\subsubsection{Requlatory requirements}

Regulatory requirements for ground water and surface water sampling at the Belfield processing site are specified in 40 CFR Part 192 (1994).

\subsubsection{Compliance monitoring}

Compliance monitoring is not required at the Belfield processing site. Future compliance monitoring requirements will be determined during the ground water remediation phase of the UMTRA Project.

\subsubsection{Site characterization}

Water sampling will not be conducted for site characterization cluring 1994. 
Table 2.3 Summary of ground water quality in the lignite zone at the Belfield processing site, North Dakota

\begin{tabular}{|c|c|c|c|}
\hline \multirow[b]{2}{*}{ Constituent } & \multirow[b]{2}{*}{$\mathrm{RMCL}^{\mathrm{C}}$} & Background ${ }^{\mathbf{a}}$ & On-site/downgradient $t^{b}$ \\
\hline & & \multicolumn{2}{|c|}{ (Median values) } \\
\hline Ammonium & & 0.13 & 0.50 \\
\hline Antimony & & 0.015 & 0.014 \\
\hline Arsenic & 0.05 & 0.005 & 0.005 \\
\hline Cadmium & 0.01 & 0.001 & 0.003 \\
\hline Calcium & & 156.0 & 127.0 \\
\hline Chloride & & 9.5 & 41.7 \\
\hline Chromium & 0.05 & 0.019 & 0.023 \\
\hline Iron & & 0.34 & 0.15 \\
\hline Lead & 0.05 & 0.007 & 0.018 \\
\hline Magnesium & & 82.2 & 86.4 \\
\hline Manganese & & 0.35 & 0.28 \\
\hline Molybdenum & 0.10 & 0.08 & 0.08 \\
\hline Net gross alpha & 15.00 & 3.56 & 11.20 \\
\hline Nitrate & 44.0 & 1.0 & 1.0 \\
\hline Potassium & & 7.49 & 7.56 \\
\hline Radium (-226 and -228$)$ & 5.00 & 0.37 & 0.75 \\
\hline Selenium & 0.01 & $0.008^{d}$ & $0.015^{d}$ \\
\hline Sodium & & 333.4 & 671.4 \\
\hline Sulfate & & 952 & 1479 \\
\hline Uranium & 0.044 & 0.001 & 0.001 \\
\hline Vanadium & & 0.024 & 0.043 \\
\hline Total dissolved solids & & 1856 & 2764 \\
\hline $\mathrm{pH}$ & & 7.00 & 6.89 \\
\hline
\end{tabular}

aMonitor well: BEL-01-0541.

'Monitor wells: BEL-01-0521, -0540 .

COncentrations in milligrams per liter; activities of net gross alpha and radium in picocuries per liter.

Maximum value exceeds maximum concentration limit. 


\subsubsection{Risk assossment}

Water sampling will not be conducted for risk assessment during 1994.

\subsection{WATER SAMPLING PLAN}

Water sampling activities are not scheduled for 1994 because ground water conditions at the site are relatively stable, the 1993 sampling was comprehensive, and surface remediation activities are not scheduled to start until 1996. The next water sampling event is scheduled before the start of remedial activities. Selected monitor wells at the sites and several domestic wells in the vicinity will be sampled. 


\subsection{BOWMAN PROCESSING/DISPOSAL SITE}

3.1

\section{SITE CONCEPTUAL MODEL}

The conceptual site model is based on available hydrogeologic information, water quality data, site reconnaissance, and data from monitor wells in the saturated units beneath the site (Figure 3.1 and Table 3.1). The conceptual site model is discussed below.

\subsubsection{Physiographic setting}

The Bowman site is in the Missouri Plateau of the northern Great Plains physiographic province. The region is drained by the Missouri River, which flows east through the center of the Williston Basin. The terrain in the site vicinity consists of gently rolling grassland.

\subsubsection{Geology}

The Bowman processing site is underlain by sediments of the Bullion Cireek Formation, which is part of the Tertiary Fort Union Group. The Bullion Creek Formation consists of approximately 40 to $60 \mathrm{ft}(12$ to $18 \mathrm{~m})$ of alternating beds of semiconsolidated claystone, siltstone, sandstone, and lignite, with varying amounts of carbonaceous material. The formation dips northeastward at approximately $20 \mathrm{ft} / \mathrm{mi}(4 \mathrm{~m} / \mathrm{km})$. Lithologic logs from the monitor wells at the Bowman site indicate that a 30 to $40 \mathrm{ft}(9$ to $12 \mathrm{~m}$ ) interbedded sequence of silty sandstone, silty claystone, and thin discontinuous lignite stringers underlies a thin soil cover (Figures 3.1 and 3.2). This hydrogeologic unit is called the upper zone of fine-grained sediments. The upper zone is underlain by a relatively extensive lignite unit that varies from 4 to $7 \mathrm{ft}(1.2$ to $2.1 \mathrm{~m})$ in thickness. This hydrogeologic unit is called the middle lignite zone. The lignite zone is underlain by an interbedded sequence similar to the upper zone. This hydrogeologic unit is called the lower zone of fine-grained sediments.

\subsubsection{Hydrology}

Ground water occurs in fine-grained sediments and fractured lignites under unconfined to confined conditions at the Bowman processing site, with water levels ranging from 6 to $20 \mathrm{ft}(1.8$ to $6 \mathrm{~m})$ below the ground surface. The ground water system in the site vicinity is recharged directly by precipitation and by seepage from intermittent streams and standing surface water. Ground water recharge to the lignite zone and the lower zone is influenced by downward leakage through the upper zones and by ground water underflow. There is no evidence of natural discharge of ground water from the upper zone or the lignite zone to the land surface or surface water in the site vicinity. Seasonal fluctuations of the potentiometric surfaces of the upper and the lignite zones generally are less than $3 \mathrm{ft}(0.9 \mathrm{~m}$ ) (from lowest to highest ground water 

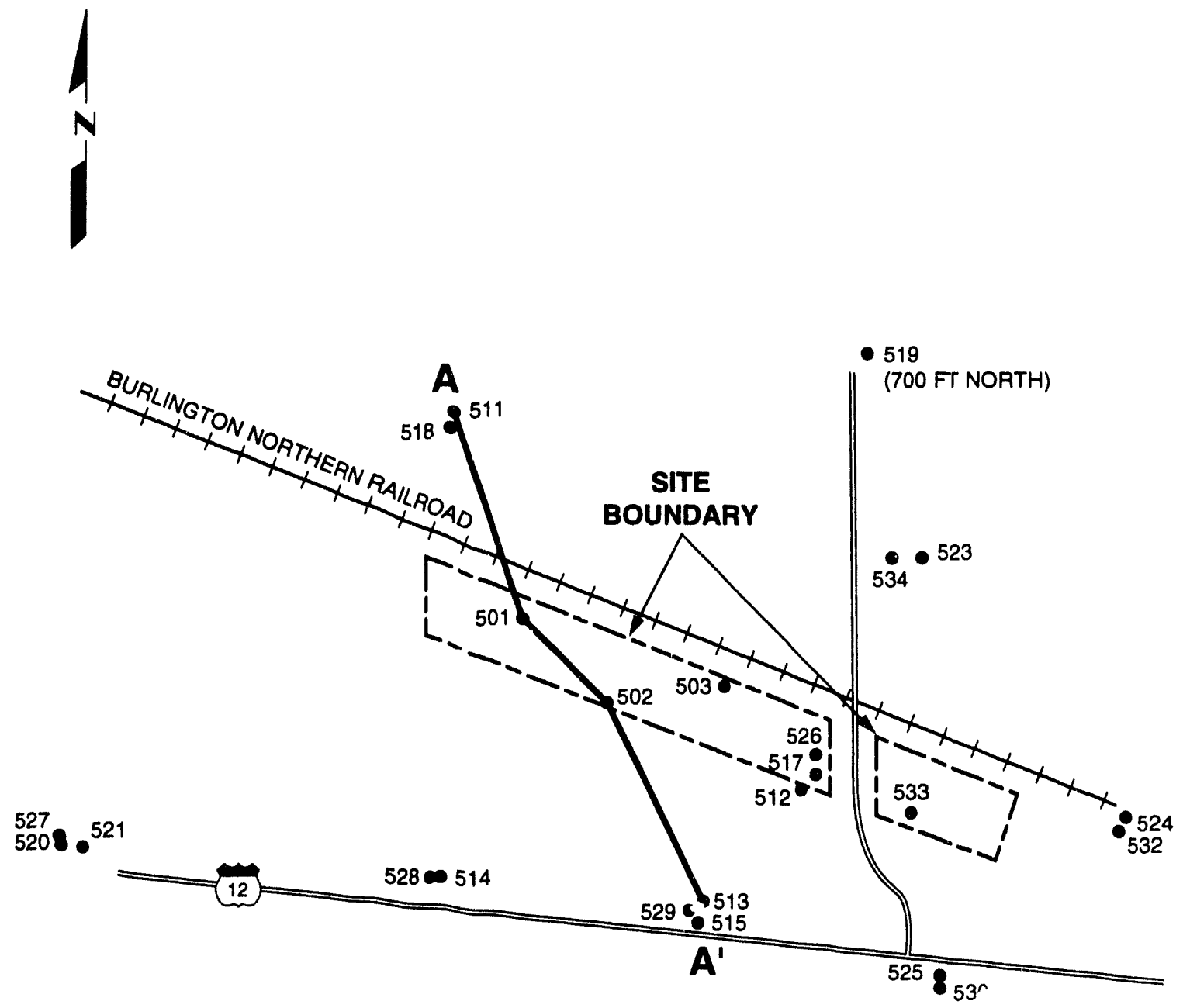

${ }_{516}^{531} 522$

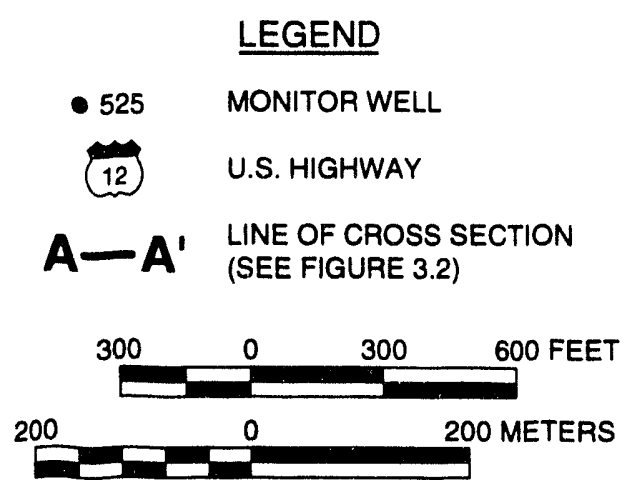

FIGURE 3.1

LOCATION OF MONITOR WELLS AT THE BOWMAN PROCESSING SITE, NORTH DAKOTA 
Table 3.1 Monitor well information for the Bowman processing site, North Dakota

\begin{tabular}{|c|c|c|c|c|c|c|c|c|c|c|c|c|}
\hline$\underset{\text { LOCATION }}{\text { LOW }}$ & $\begin{array}{c}\text { WORTH } \\
\text { COORDIMATE } \\
\text { (FT) }\end{array}$ & $\begin{array}{c}\text { EAST } \\
\text { COORDIMATE } \\
\text { (FT) }\end{array}$ & $\begin{array}{c}\text { GROOND } \\
\text { ELEVATION } \\
\text { (FT MSL) }\end{array}$ & $\begin{array}{l}\text { BOREHOLE } \\
\text { DEPTH } \\
\text { (FT) }\end{array}$ & $\begin{array}{l}\text { BOREHOLE } \\
\text { DIAMETER } \\
\text { (INCHES) }\end{array}$ & $\begin{array}{l}\text { CASING } \\
\text { ELEVATION } \\
\text { (FT MSL) }\end{array}$ & $\begin{array}{l}\text { CASIMG } \\
\text { DEPTH } \\
\text { (FT) }\end{array}$ & $\begin{array}{l}\text { CASING } \\
\text { DIAMETER } \\
\text { (INCHES) }\end{array}$ & $\mid \begin{array}{c}\text { SCREEN } \\
\text { BEGINHING } \\
\text { DEPTH (FT) }\end{array}$ & $\begin{array}{l}\text { SCREEN } \\
\text { LENGTH } \\
\text { (FT) }\end{array}$ & $\begin{array}{l}\text { FLOW } \\
\text { COOE }\end{array}$ & $\begin{array}{c}\text { FOMmation } \\
\text { OF } \\
\text { COMPLETION }\end{array}$ \\
\hline $\begin{array}{l}0501 \\
0502 \\
0503 \\
0511 \\
0512 \\
0513 \\
0514 \\
0515 \\
0516 \\
0517 \\
0518 \\
0519 \\
0520 \\
0521 \\
0522 \\
0523 \\
0524 \\
0525 \\
0526 \\
0527 \\
0528 \\
0529 \\
0530 \\
0531 \\
0532 \\
0533 \\
0534\end{array}$ & $\begin{array}{c}50896.6 \\
50534.3 \\
50631.7 \\
51473.0 \\
50254.6 \\
49894.6 \\
49988.2 \\
49885.1 \\
49682.3 \\
56267.1 \\
51454.2 \\
52020.2 \\
50087.78 \\
50086.24 \\
49691.56 \\
50984.25 \\
50166.61 \\
49649.13 \\
50287.79 \\
- \\
- \\
- \\
- \\
-\end{array}$ & $\begin{array}{c}50355.5 \\
50564.5 \\
50942.4 \\
50114.4 \\
51265.7 \\
50890.2 \\
50054.3 \\
50889.3 \\
52620.3 \\
51275.4 \\
50109.9 \\
51375.8 \\
48879.75 \\
48890.13 \\
52610.96 \\
51577.32 \\
52217.05 \\
51610.27 \\
51279.14 \\
- \\
- \\
- \\
- \\
- \\
-\end{array}$ & $\begin{array}{c}3053.90 \\
3053.20 \\
3050.80 \\
3060.30 \\
3049.20 \\
3057.50 \\
3048.50 \\
3057.60 \\
3045.60 \\
3049.10 \\
3060.40 \\
3061.10 \\
3052.84 \\
3052.76 \\
3045.67 \\
3052.86 \\
3047.63 \\
3052.55 \\
3049.12 \\
- \\
- \\
- \\
-\end{array}$ & $\begin{array}{l}30.00 \\
30.00 \\
30.00 \\
95.00 \\
95.00 \\
95.00 \\
40.00 \\
45.00 \\
40.00 \\
30.00 \\
45.00 \\
45.00 \\
60.00 \\
100.00 \\
100.00 \\
50.00 \\
42.00 \\
57.50 \\
50.00 \\
42.63 \\
24.81 \\
35 . \\
44.66 \\
25 . \\
27.15 \\
34.09 \\
37 .\end{array}$ & $\begin{array}{l}8.000 \\
8.000 \\
8.000 \\
6.630 \\
6.630 \\
6.630 \\
6.630 \\
8.630 \\
6.630 \\
6.630 \\
6.630 \\
6.630 \\
7.875 \\
7.875 \\
7.875 \\
7.875 \\
7.875 \\
7.875 \\
7.875 \\
8 . \\
8 . \\
8 . \\
8 . \\
8 . \\
8 . \\
8 . \\
8 .\end{array}$ & $\begin{array}{c}3055.38 \\
3054.62 \\
3052.28 \\
3062.37 \\
3051.18 \\
3059.53 \\
3050.43 \\
3059.51 \\
3047.49 \\
3050.83 \\
3062.27 \\
3063.06 \\
3055.17 \\
3054.63 \\
3047.87 \\
3055.34 \\
3049.48 \\
3054.93 \\
3050.66 \\
- \\
- \\
- \\
-\end{array}$ & $\begin{array}{c}32.00 \\
32.00 \\
32.00 \\
97.00 \\
97.00 \\
97.00 \\
42.00 \\
47.00 \\
42.00 \\
31.66 \\
46.80 \\
47.00 \\
62.50 \\
102.50 \\
102.50 \\
52.50 \\
42.50 \\
60.00 \\
52.50 \\
44.51 \\
26.5 \\
35.7 \\
46.38 \\
27.4 \\
29.08 \\
36.97 \\
38.35\end{array}$ & $\begin{array}{l}4.000 \\
4.000 \\
4.000 \\
2.000 \\
2.000 \\
2.000 \\
2.000 \\
2.000 \\
2.000 \\
2.000 \\
2.000 \\
2.000 \\
4.000 \\
4.000 \\
4.000 \\
4.000 \\
4.000 \\
4.000 \\
4.000 \\
4 . \\
4 . \\
4 . \\
4 . \\
4 . \\
4 . \\
4 . \\
4 .\end{array}$ & $\begin{array}{l}22.00 \\
10.00 \\
17.00 \\
75.00 \\
75.00 \\
75.00 \\
30.00 \\
35.00 \\
30.00 \\
19.66 \\
34.80 \\
35.00 \\
50.00 \\
80.00 \\
80.00 \\
40.00 \\
30.00 \\
47.60 \\
40.00 \\
. \\
\div \\
- \\
13 . \\
15.15 \\
22.90 \\
25 .\end{array}$ & $\begin{array}{l}10.0 \\
22.0 \\
15.0 \\
20.0 \\
20.0 \\
20.0 \\
10.0 \\
10.0 \\
10.0 \\
10.0 \\
10.0 \\
10.0 \\
10.0 \\
20.0 \\
20.0 \\
10.0 \\
10.0 \\
10.0 \\
10.0 \\
10 . \\
10 . \\
10 . \\
10 . \\
10 . \\
10 . \\
10 . \\
10 .\end{array}$ & $\begin{array}{l}N \\
N \\
N \\
N \\
N \\
N \\
N \\
N \\
N \\
N \\
N \\
N \\
N \\
N \\
N \\
N \\
N \\
N \\
N \\
N \\
N \\
N \\
N \\
N \\
N \\
N\end{array}$ & $\begin{array}{l}T H \\
T N \\
T N \\
T N \\
T N \\
T N \\
T N \\
T N \\
T N \\
T N \\
T N \\
T N \\
T N \\
T N \\
T N \\
T N \\
T N \\
T N \\
T N \\
A L \\
A L \\
A L \\
A L \\
A L \\
A L \\
A L \\
A L\end{array}$ \\
\hline
\end{tabular}

FORMATION OF COMPLETION CODE:

TN - BULLION CREEK FORMATION

FLON RELATIONSHIP CODE:

AL - ALLUVIUM

N - UNKMONN

DATA FILE: M: DDARTIBONO1 MMHI 10001.DAT

FIELDS DISPLAYEd WITH a DASH IMdicate the data IS UMAVAILABLE 


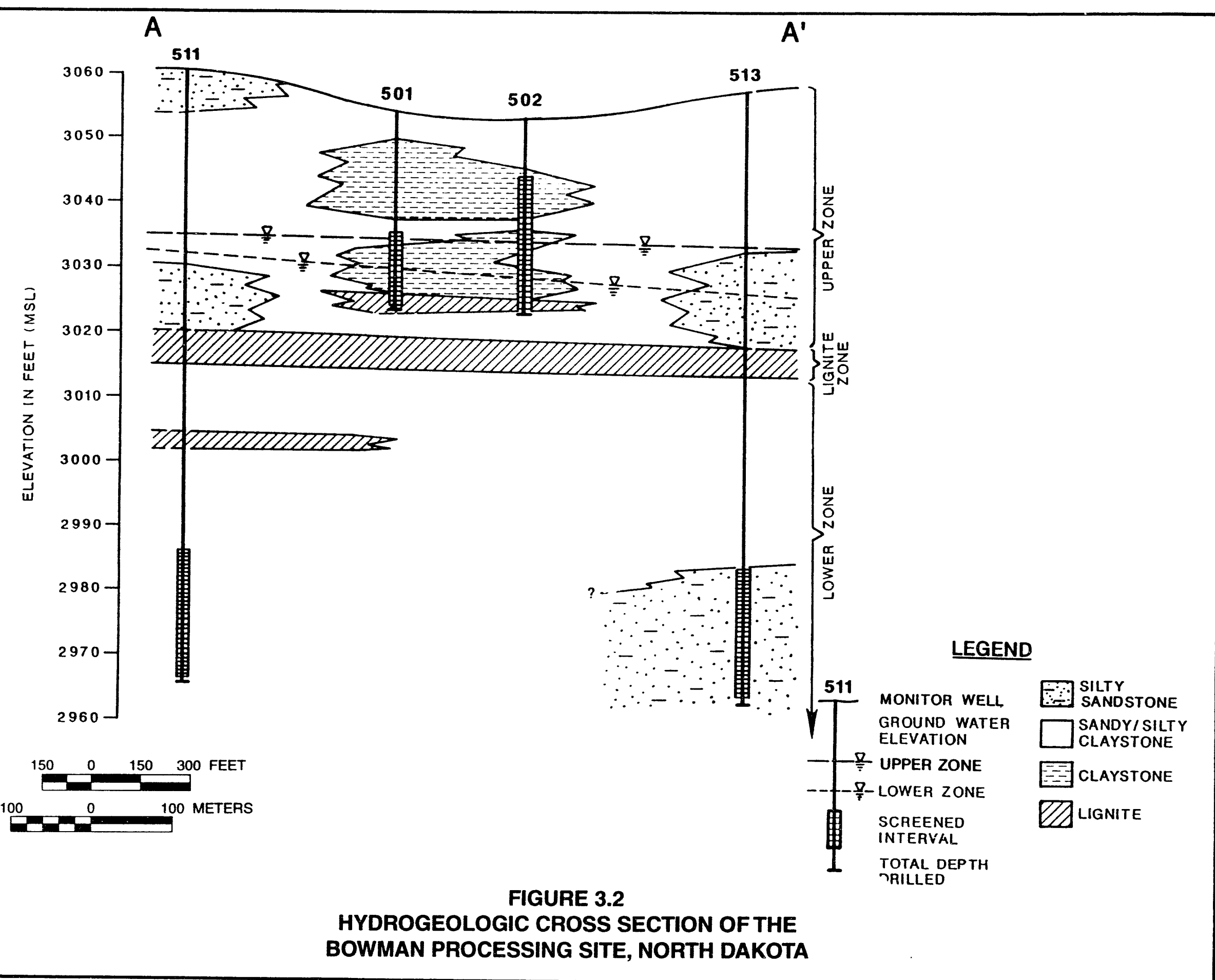


elevation). These water levels fluctuate in response to spring snowmelt and periods of maximum precipitation in the summer and fall.

Ground water in this area flows generally east and northeast. The water table configuration in the upper zone indicates a northwest-southeast trending ridge (from monitor well BOW-01-0517 to -0530), with local ground water flow northeast and southwest at a gradient of approximately 0.004 (Figure 3.3). These data indicate the saturated interval in the upper zone is not a laterally continuous, integrated aquifer unit but consists of ground water in perched zones and in heterogeneous units wi+' 'ateral and vertical facies variations (with a predominance of clay- and silt-siz, , material). There is hydraulic interconnection within this saturated interval, but varying water levels result from differential equilibration of water percolating through the interval. The potentiometric surface of the lignite zone indicates that the ground water flows generally southeast, with a hydraulic gradient averaging 0.002 or less (Figure 3.4). The hydraulic gradient observed in the lignite zone is low because the low topographic relief in the area and the higher transmissivity in the fractured lignite zone facilitate equilibration of the ground water levels. The potentiometric surface of the lower zone indicates ground water flows generally east and southeast, with a hydraulic gradient of 0.005 .

To determine the vertical hydraulic gradient, ground water elevations were compared in adjacent monitor wells screened in all three hydrogeologic zones. Ground water elevations generally were higher in the upper zone than in the lignite and lower zones, indicating a downward hydraulic gradient.

Aquifer pumping tests in selected monitor wells measured hydraulic parameters in all three hydrogeologic units in the Bowman site vicinity. The average hydraulic conductivity of the upper zone was estimated to be $0.23 \mathrm{ft} / \mathrm{day}(8.1 \times$ $10^{-5} \mathrm{~cm} / \mathrm{s}$ ). The average hydraulic conductivity of the lignite zone was estimated to be $10.21 \mathrm{ft} / \mathrm{day}\left(3.6 \times 10^{-3} \mathrm{~cm} / \mathrm{s}\right)$. The average hydraulic conductivity of the lower zone was estimated to be $0.15 \mathrm{ft} /$ day $(5.3 \times$ $\left.10^{-5} \mathrm{~cm} / \mathrm{s}\right)$.

Based on an average hydraulic conductivity of $0.23 \mathrm{ft} / \mathrm{day}\left(8.1 \times 10^{-5} \mathrm{~cm} / \mathrm{s}\right)$, an average hydraulic gradient of 0.004 , and an estimated effective porosity of 0.20 , the average linear ground water velocity for the upper zone was $4.6 x$ $10^{-3} \mathrm{ft} /$ day $\left(1.6 \times 10^{-6} \mathrm{~cm} / \mathrm{s}\right)$. Based on an average hydraulic conductivity of $10.2 \mathrm{ft} / \mathrm{day}\left(3.6 \times 10^{-3} \mathrm{~cm} / \mathrm{s}\right)$, an average hydraulic gradient of 0.001 , and an estimated effective porosity of 0.05 , the average linear ground water velocity for the lignite zone was $0.20 \mathrm{ft} /$ day $\left(7.1 \times 10^{-5} \mathrm{~cm} / \mathrm{s}\right)$. Based on an average hydraulic conductivity of $0.15 \mathrm{ft} /$ day $\left(5.3 \times 10^{-5} \mathrm{~cm} / \mathrm{s}\right)$, an average gradient of 0.005 , and an estimated effective porosity of 0.20 , the average linear ground water velocity for the lower zone was $3.8 \times 10^{-3} \mathrm{ft} / \mathrm{day}\left(1.3 \times 10^{-6} \mathrm{~cm} / \mathrm{s}\right)$. 

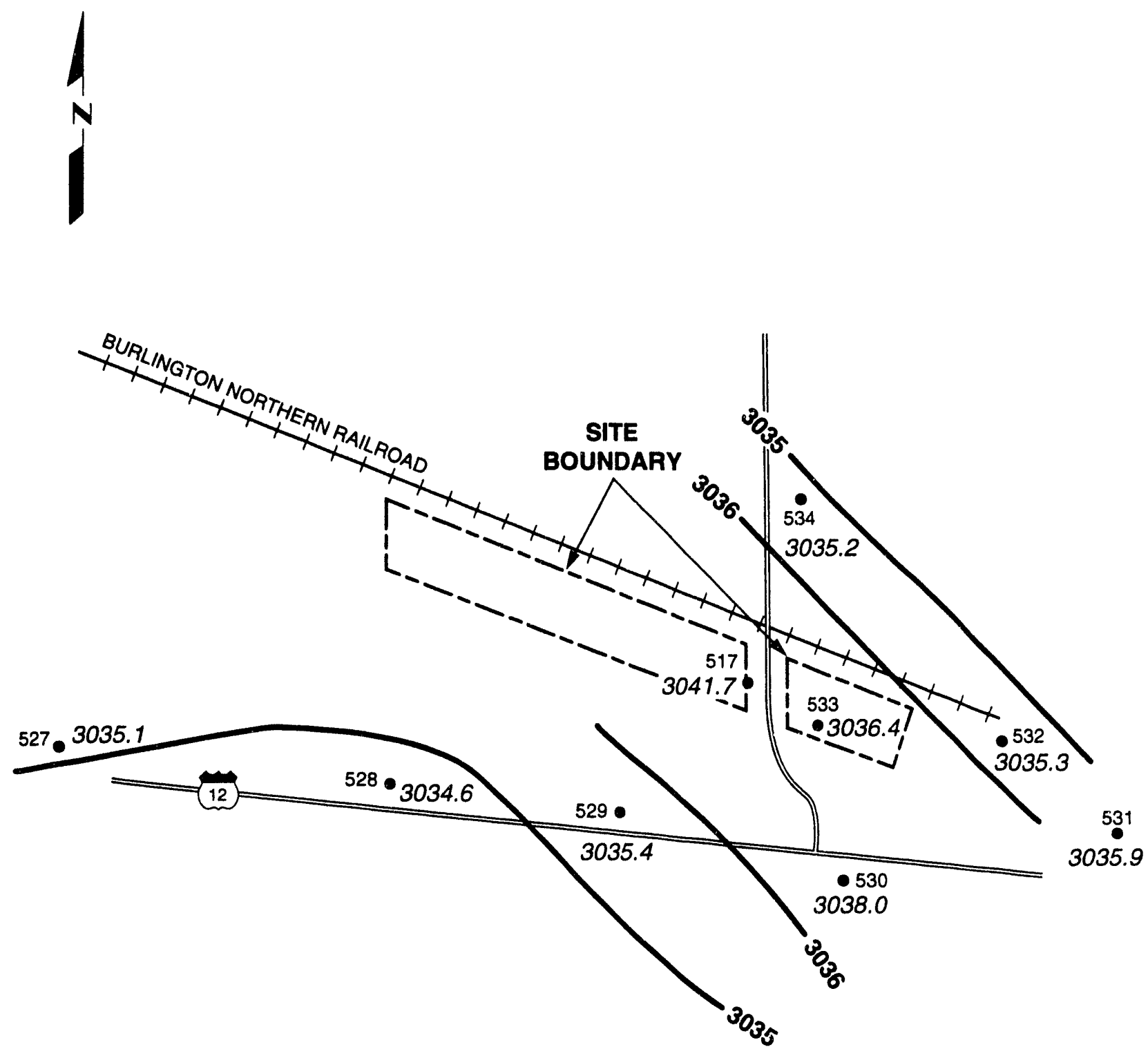

\section{LEGEND}

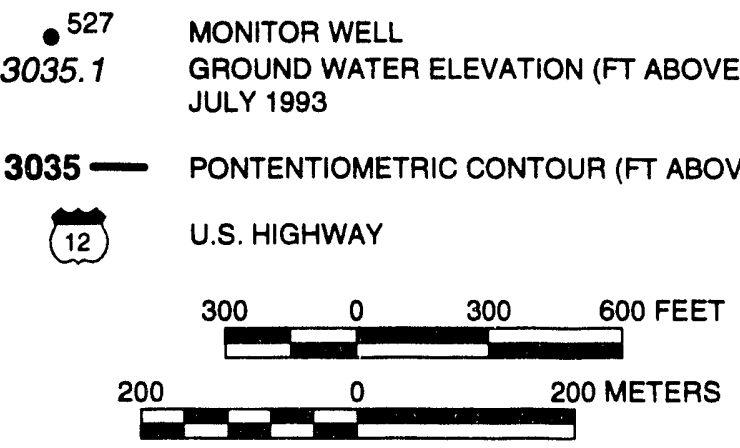

FIGURE 3.3

POTENTIOMETRIC SURFACE OF THE UPPER ZONE AT THE BOWMAN PROCESSING SITE, NORTH DAKOTA 

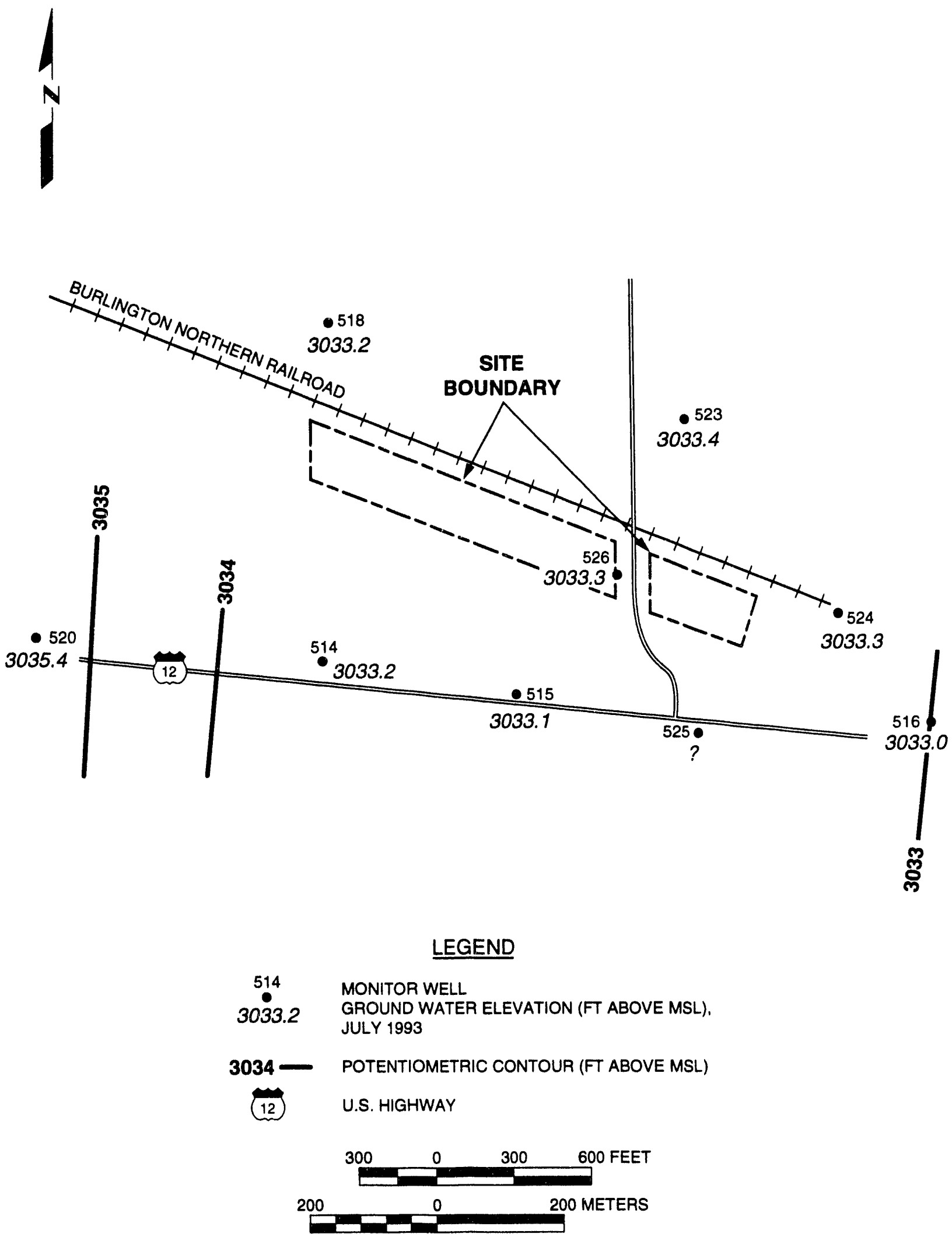

FIGURE 3.4

POTENTIOMETRIC SURFACE OF THE LIGNITE ZONE AT THE BOWMAN PROCESSING SITE, NORTH DAKOTA 


\subsubsection{Water quality}

Water quality sampling was conducted at the Bowman site from 1986 until 1993. A comprehensive list of constituents was analyzed during screening monitoring to determine background and baseline ground water quality in the zones of interest beneath the site. This list was modified during subsequent sampling events to focus on the following constituents related to uranium processing activities and standard field and geochemical parameters: ammonium, antimony, arsenic, cadmium, calcium, chromium, chloride, gross alpha, iron, lead, magnesium, manganese, molybdenum, nitrate, potassium, radium-226 and -228 , selenium, sodium, sulfate, total dissolved solids, total organic carbon, uranium, and vanadium.

\section{Background ground water quality}

Background ground water quality in the upper zone was determined by analyzing samples collected from monitor wells BOW-01-0519 and -0527 (Figure 3.1). Background ground water quality data from these monitor well show that activities of net gross alpha and radium-226 and -228 exceed the proposed EPA MCLs. Background ground water quality in the lignite zone was determined by analyzing samples collected from monitor wells BOW-01-0518 and -0520 (Figure 3.1). Ground water quality data from these monitor wells show that chromium and selenium concentrations and net gross alpha and radium activities exceed the proposed EPA MCLs. Similar concentrations of these constituents were also observed in off-site domestic wells. Background ground water quality in the lower zone was determined by analyzing samples collected from monitor wells BOW-01-0511 and -0521 (Figure 3.1). Data from these monitor wells show that maximum concentrations of constituents were below the MCLs.

\section{Extent of existing ground water contamination}

Kerr-McGee operated an ashing plant to process uraniferous lignite at the Bowman processing site from 1964 to 1967 . The processing operation consisted of drying and burning lignite in a rotary kiln. This operation involved only combustion of the organic material. No chemical, metallurgical, or nuclear processes were used. Airborne contamination was minimal due to the completely enclosed ashing circuit and the scrubber system on the stack. Ash from the kiln was air-cooled in a rotary cooler, loaded into railroad cars, and shipped to the Kerr-McGee uranium ore processing plant at Ambrosia Lake, New Mexico. Sources of soil and ground water contamination at the Bowman processing site resulting from the lignite ashing operations include water seepage from stockpiled lignite prior to ashing operations, ash and dust released to the atmosphere during the process, and sludges and residues from the stack gas-scrubber. Surface water runoff from the site may have transported suspended and dissolved contaminants into ponded areas and drainages near the site. 
Contaminant concentrations in the soil pore fluid were analyzed from samples collected from five suction Iysimeters (BOW-0572, -0573, -0575, -0576, and -0577 ) on the processing site and completed to depths ranging from 6 to $12 \mathrm{ft}$ $(1.8$ to $3.7 \mathrm{~m}$ ) below the ground surface (Figure 3.1). Concentrations of cadmium, chromium, lead, molybdenum, selenium, and uranium exceeded the proposed EPA MCLs in the lysimeter samples but were generally within the same order of magnitude as the MCLs.

Ground water samples collected from on-site and downgradient monitor wells at the Bowman processing site were analyzed to determine the extent and magnitude of ground water contamination related to the uranium processing activities. In the upper zone, average concentrations of molybdenum, selenium, and uranium in ground water exceeded the proposed EPA MCLs (Table 3.2). Nitrate concentrations were approximately two times higher than the EPA MCL in monitor well BOW-01-0517 and probably result from agricultural activities. Contaminants in ground water that exceed background concentrations do not form a discrete plume in the upper zone downgradient from the processing site (Figures 3.5 and 3.6). The extent of ground water contamination in the lignite zone is less than ground water contamination in the fine-grained sediments of the upper zone (Table 3.3). This difference is a result of dilution by ground water flowing through the more transmissive fractured lignite, and the relative reducing capacity of the lignite (which tends to precipitate uranium and other constituents out of solution). Concentrations of selenium and activities of net gross alpha and radium exceed the proposed EPA MCLs in ground water. In the lower zone the concentrations of all constituents considered in the proposed EPA ground water standards were below MCLs.

Some constituents of concern (such as antimony, chromium, lead, molybdenum, selenium, uranium, and vanadium) occur at naturally elevated concentration in shallow ground water adjacent to lignite zones in this region of North Dakota. This has made it difficult to distinguish between the potential extent and impact of ground water contamination related to the former uranium processing activities at this site and the impact of naturally occurring concentrations of these constituents on the environment. Possible sources of nitrate are fertilizer applied to crop areas, farmyard wastes, and septic tank effluent.

\subsection{DATA COLLECTION OBJECTIVES}

DOOs identify the reasons for collecting data, which are regulatory requirements, compliance monitoring, site characterization, risk assessment, and other considerations.

DOOs define the manner in which samples are collected, handled, and analyzed. DQOs define analytical support levels; follow standard procedures for water sampling, preservation, transport, and various other field procedures; ensure procedures follow $\mathrm{QA}$ and $\mathrm{OC}$ protocols; and provide analytical data validation. DQOs for data collection and evaluation activities are stated in the WSAP guidance document (DOE, 1993), the QAIP, and applicable SOPS (JEG, n.d.). 
Table 3.2 Summary of ground water quality in the upper zone at the Bowman processing site, North Dakota

\begin{tabular}{|c|c|c|c|}
\hline & & Background $^{\mathbf{2}}$ & On-site/downgradient ${ }^{b}$ \\
\hline Constituent & $\mathrm{MCL}^{\mathrm{C}}$ & \multicolumn{2}{|c|}{ (Median values) } \\
\hline Ammonium & & 0.52 & 0.41 \\
\hline Antimony & & 0.007 & 0.005 \\
\hline Arsenic & 0.05 & 0.005 & 0.005 \\
\hline Cadmium & 0.01 & 0.002 & 0.002 \\
\hline Calcium & & 81.9 & 241.3 \\
\hline Chloride & & 7.4 & 14.3 \\
\hline Chromium & 0.05 & 0.010 & 0.010 \\
\hline Iron & & 0.61 & 0.04 \\
\hline Lead & 0.05 & 0.005 & 0.006 \\
\hline Magnesium & & 49.0 & 265.2 \\
\hline Manganese & & 0.60 & 0.27 \\
\hline Molybdenum & 0.10 & 0.01 & $0.01^{d}$ \\
\hline Net gross alpha & 15.00 & 8.30 & $7.51^{d}$ \\
\hline Nitrate & 44.0 & 1.0 & $2.7^{d}$ \\
\hline Potassium & & 13.98 & 22.83 \\
\hline Radium $(-226$ and -228$)$ & 5.00 & 2.26 & 3.08 \\
\hline Selenium & 0.01 & 0.005 & $0.005^{d}$ \\
\hline Sodium & & 367.3 & 783.5 \\
\hline Sulfate & & 787 & 3266 \\
\hline Uranium & 0.044 & 0.001 & $0.033^{d}$ \\
\hline Vanadium & & 0.01 & 0.01 \\
\hline Total dissolved solids & & 1586 & 5163 \\
\hline $\mathrm{pH}$ & & 6.78 & 6.82 \\
\hline
\end{tabular}

a Background monitor wells: BOW-01-0519, -0527.

bOn-site/downgradient monitor wells: BOW-01-0517, $-0528,-0529,-0530,-0531,-0532$, -0533 , and -0534.

${ }^{\mathrm{C}}$ Concentrations in milligrams per liter; activities of net gross alpha and radium in picocuries per liter.

Maximum value exceeds maximum concentration limit. 


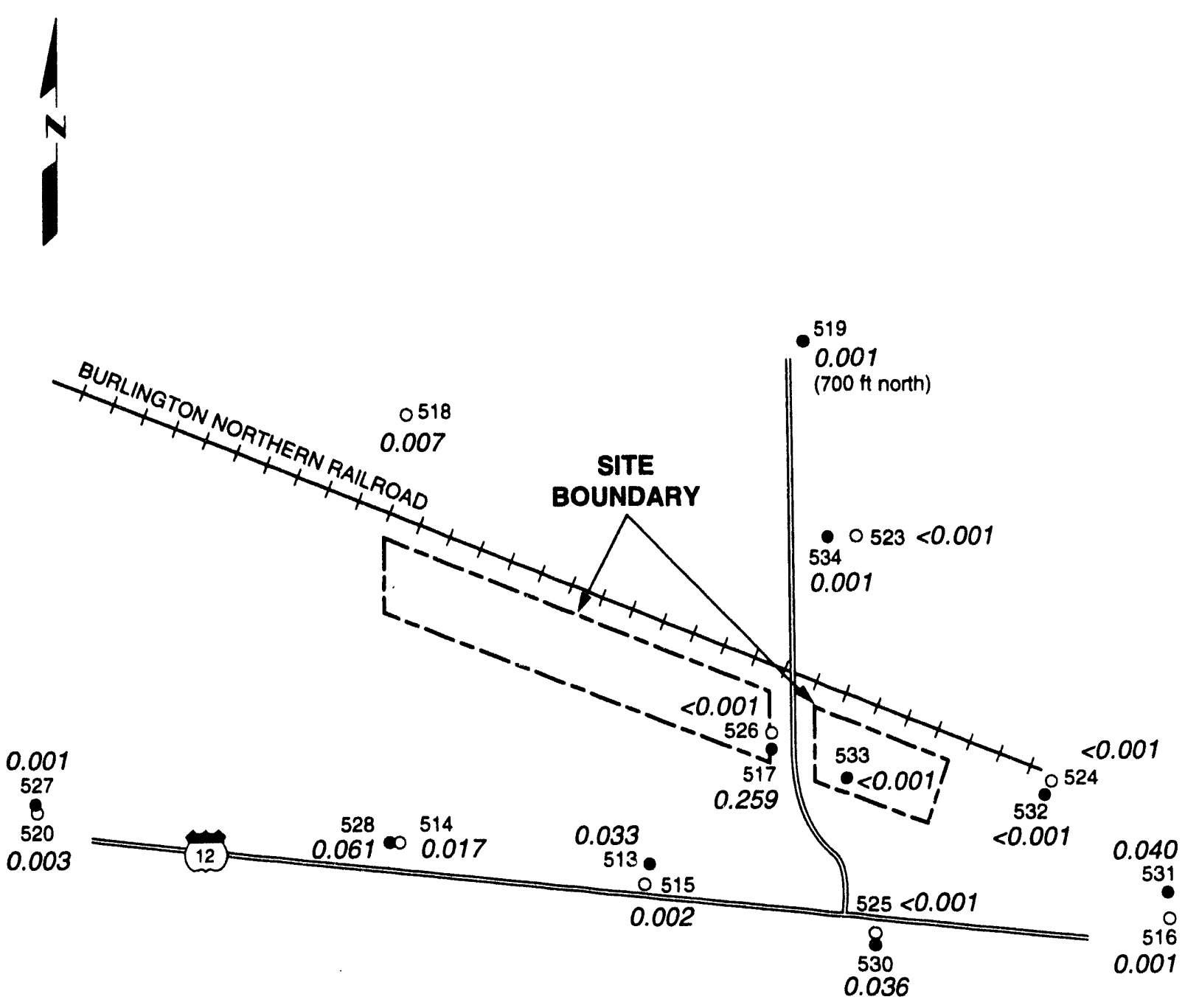

\section{LEGEND}

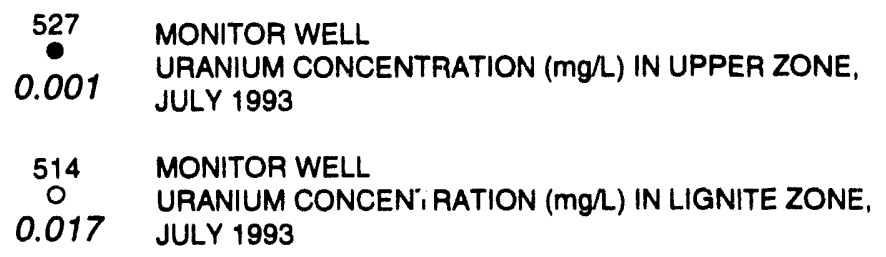

(12) U.S. HIGHWAY

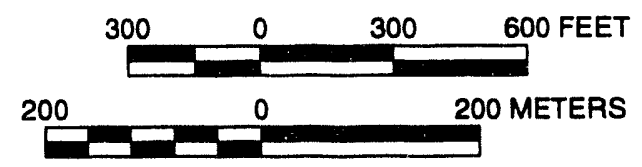

FIGURE 3.5

URANIUM DISTRIBUTION IN THE UPPERMOST AQUIFER AT THE BOWMAN PROCESSING SITE, NORTH DAKOTA 


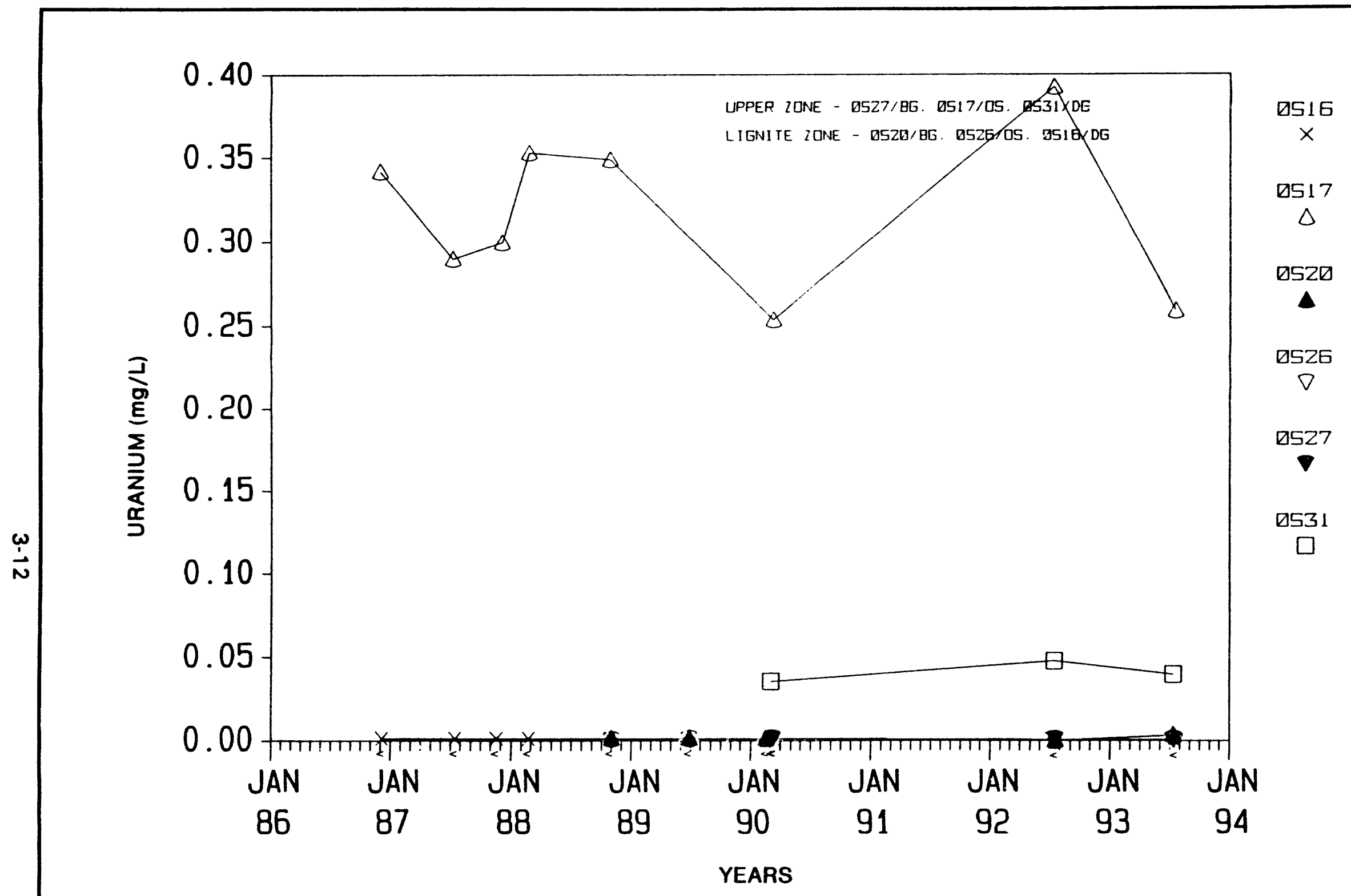

FIGURE 3.6

URANIUM CONCENTRATIONS VERSUS TIME AT THE BOWMAN PROCESSING SITE, NORTH DAKOTA 
Table 3.3 Summary of ground water quality in the lignite zone at the Bowman processing site. North Dakota

\begin{tabular}{|c|c|c|c|}
\hline & & Background ${ }^{\star}$ & On-site/Downgradient ${ }^{b}$ \\
\hline Constituent & $\mathrm{MCL}^{\mathrm{C}}$ & \multicolumn{2}{|c|}{ (Median values) } \\
\hline Ammonium & & 0.18 & 0.35 \\
\hline Antimony & & 0.011 & 0.013 \\
\hline Arsenic & 0.05 & 0.005 & 0.005 \\
\hline Cadmium & 0.01 & 0.002 & 0.002 \\
\hline Calcium & & 161.4 & 137.4 \\
\hline Chloride & & 6.9 & 8.5 \\
\hline Chromium & 0.05 & 0.019 & 0.025 \\
\hline Iron & & 1.54 & 0.71 \\
\hline Lead & 0.05 & 0.007 & 0.007 \\
\hline Magnesium & & 117.0 & 114.7 \\
\hline Manganese & & 0.54 & 0.29 \\
\hline Molybdenum & 0.10 & 0.02 & 0.03 \\
\hline Net gross alpha & 15.00 & 6.28 & $9.75 d$ \\
\hline Nitrate & 44.0 & 1.0 & 1.0 \\
\hline Potassium & & 16.96 & 17.53 \\
\hline Radium (-226 and -228 ) & 5.00 & 2.99 & $1.08^{d}$ \\
\hline Selenium & 0.01 & $0.020^{d}$ & $0.005^{d}$ \\
\hline Sodium & & 385.7 & 478.7 \\
\hline Sulfate & & 1327 & 1386 \\
\hline Uranium & 0.044 & 0.004 & 0.001 \\
\hline Vanadium & & 0.01 & 0.01 \\
\hline Total dissolved solids & & 2296 & 2484 \\
\hline $\mathrm{pH}$ & & 7.02 & 7.15 \\
\hline
\end{tabular}

aBackground monitor wells: BOW-01-0518, -0520.

bOn-site/downgradient monitor wells: BOW-01-0514, -0515, -0516, -0523, -0524, -0525, and -0526.

'Concentrations in milligrams per liter; activities of net gross alpha and radium in picocuries per liter.

Maximum value exceeds maximum concentration limit. 


\subsubsection{Bequlatory requirements}

The regulatory requirements for ground water and surface water sampling at the Bowman processing/disposal site are specified in 40 CFR Part 192 (1994).

\subsubsection{Compliance monitoring}

Compliance monitoring is not required at the Bowman processing/disposal site. The appropriate method for performance monitoring of the disposal site will be determined and described in the site long-term surveillance plan. Future compliance monitoring requirements for the ground water remediation phase will be determined later.

\subsubsection{Site characterization}

Water sampling will not be conducted for site characterization during 1994.

\subsubsection{Risk assessment}

Water sampling will not be conducted for risk assessment during 1994.

\section{WATER SAMPLING PLAN}

Water sampling activities are not scheduled for 1994 because the ground water conditions at the site are relatively stable, the 1993 sampling was comprehensive, and surface remediation activities are not scheduled to start until 1996. The next water sampling event is scheduled before the start of remedial activities and will include sampling selected monitor wells at the sites and several domestic wells in the vicinity. 


\subsection{LIST OF CONTRIBUTORS}

The following individuals contributed to the preparation of this document.

\begin{tabular}{ll}
\hline Name & Contribution \\
\hline R. Heydenburg & Overall document responsibility; author \\
A. Holm, A. Miller & Document review \\
M. Day, A. Groffman & Peer review \\
J. Torline & Technical editing \\
L. Keith & Text processing \\
B. Harvey & Graphic design \\
\hline
\end{tabular}




\subsection{REFERENCES}

DOE (U.S. Department of Energy), 1994. UMTRA Project Technical Assistance Contractor Quality Assurance Implementation Plan, DOE/AL/62350-72D, prepared by the U.S. Department of Energy, UMTRA Project Office, Albuquerque Operations Office, Albuquerque, New Mexico.

DOE (U.S. Department of Energy), 1993. Guidance Document for Preparing Water Sampling and Analysis Plans for UMTRA Sites, DOE/AL/62350-70F, DOE UMTRA Project Office, Albuquerque Operations Office, Albuquerque, New Mexico.

DOE (U.S. Department of Energy), 1992. Guidance for Implementing the UMTRA Project Long-term Surveillance Program, UMTRA-DOE/AL-350125.0000, Rev. 1, DOE UMTRA Project Office, Albuquerque Operations Office, Albuquerque, New Mexico.

DOE (U.S. Department of Energy), 1989. Technical Approach Document, UMTRADOE/AL-050425.0002, DOE UMTRA Project Office, Albuquerque Operations Office, Albuquerque, New Mf ico, p. 303.

JEG (Jacobs Engineering Group Inc.), n.d. Albuquerque Operations Manual, standard operating procedures, prepared by Jacobs Engineering Group Inc., Albuquerque, New Mexico, for the U.S. Department of Energy, UMTRA Project Office, Albuquerque Operations Office, Albuquerque, New Mexico.

\section{CODE OF FEDERAL REGULATIONS}

40 CFR Part 192, "Health and Environmental Protection Standards for Uranium and Thorium Mill Tailings," U.S. Envii onmental Protection Agency (1994).

\section{FEDERAL REGISTER}

52 FR 36000, "EPA Standards for Remedial Actions at Inactive Uranium Processing Sites; Proposed Rule," September 24, 1987. 

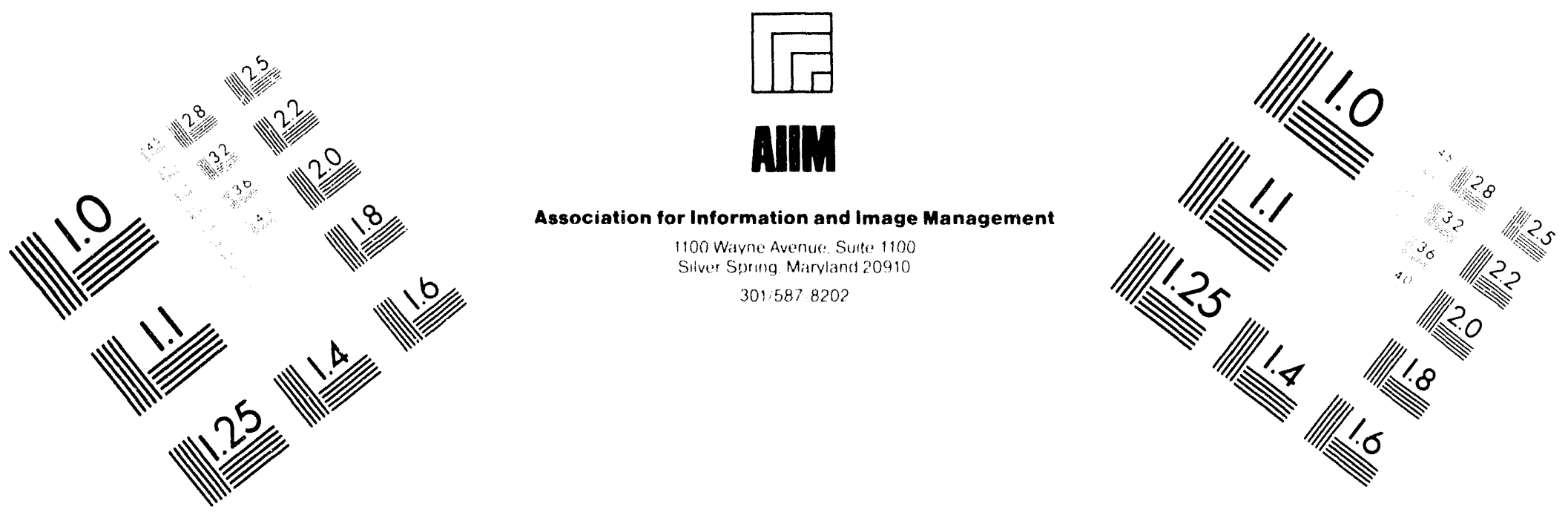

\section{Centimeter}

$\begin{array}{llllllllllllllll}1 & 2 & 3 & 4 & 5 & 6 & 7 & 8 & 9 & 10 & 11 & 12 & 13 & 14 & 15 & \mathrm{~mm}\end{array}$

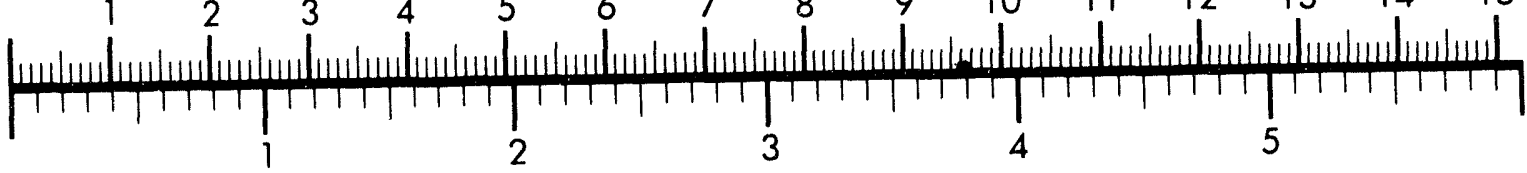
Inches
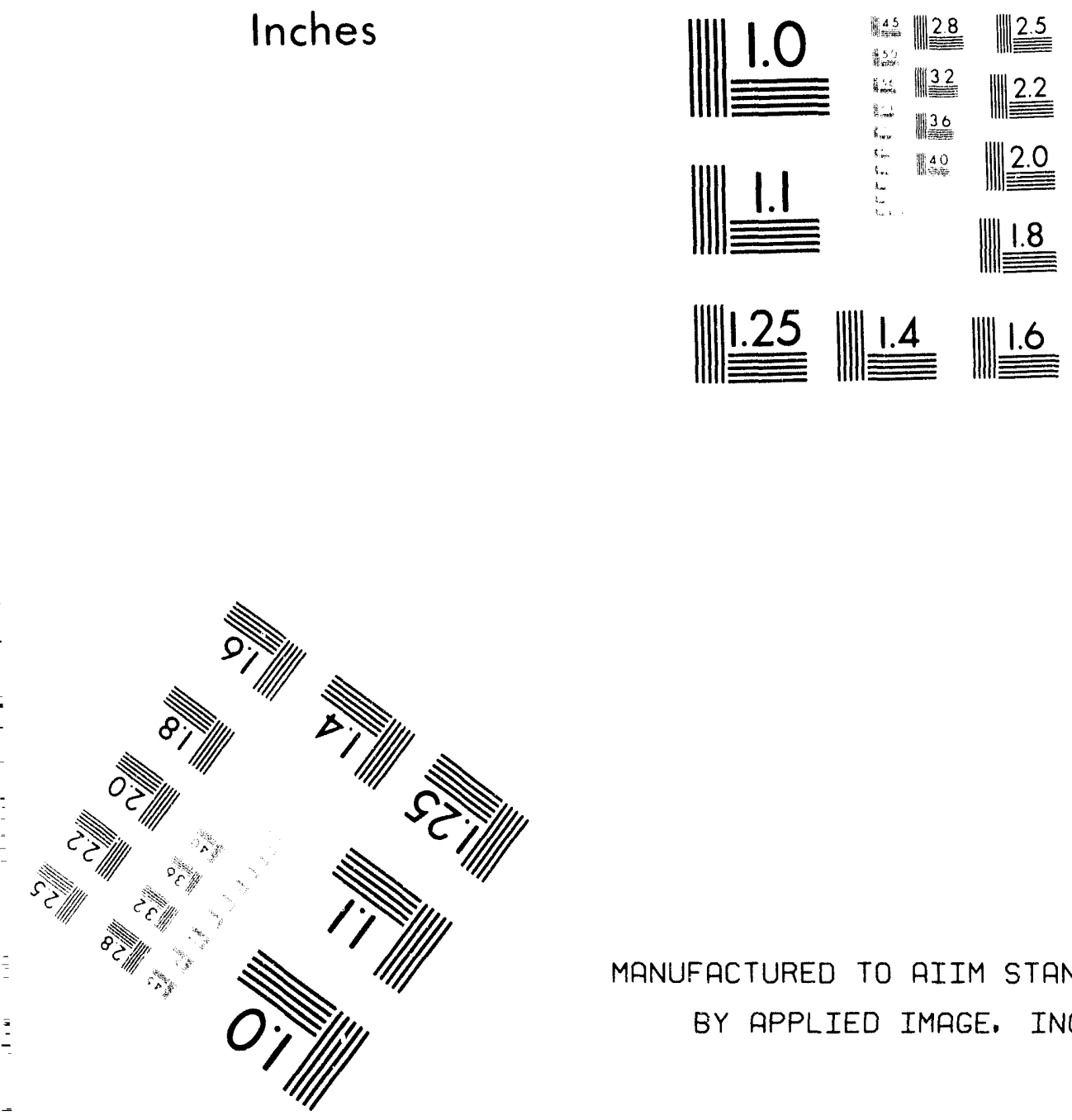

MANUFACTURED TO AIIM STANDARDS BY APPLIED IMAGE. INC.

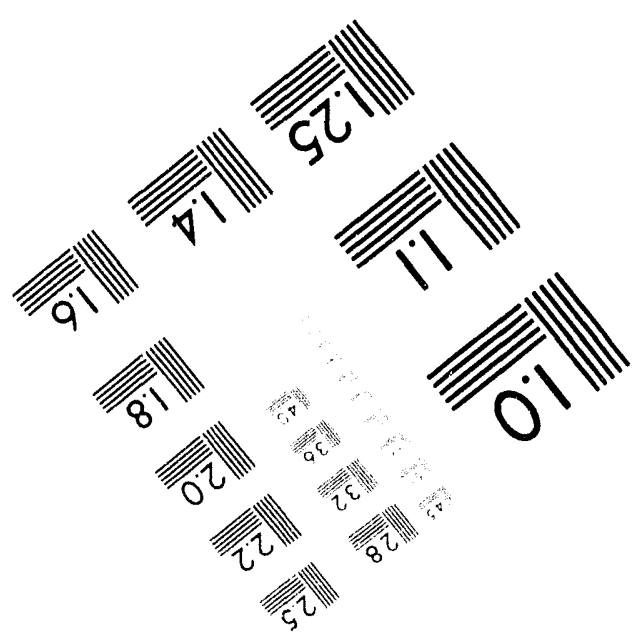



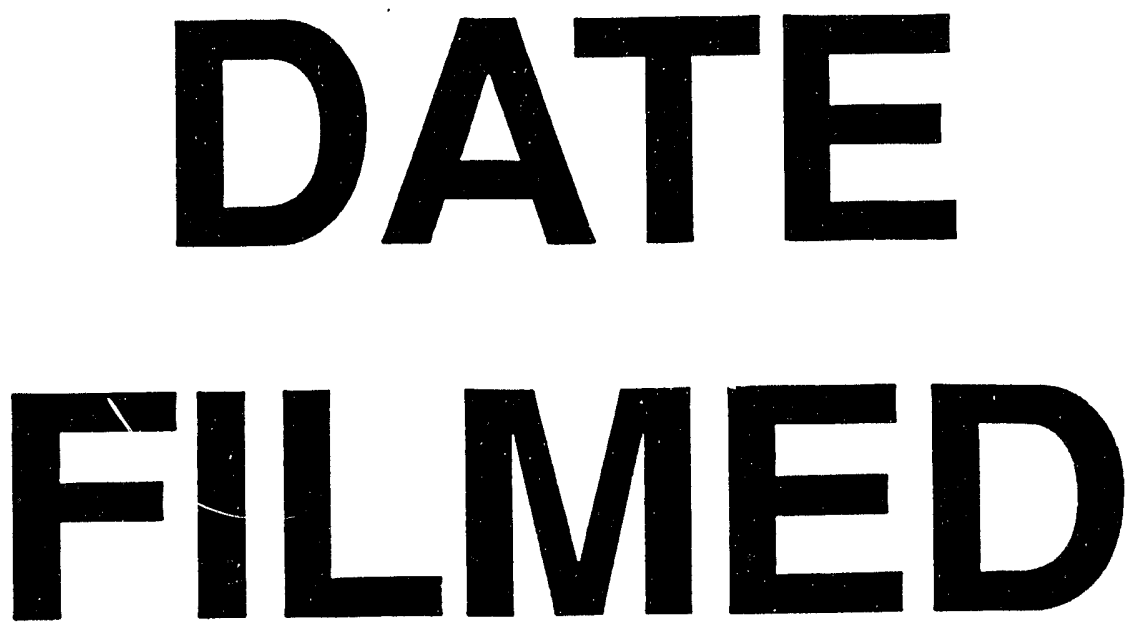

$11 / 30 / 94$
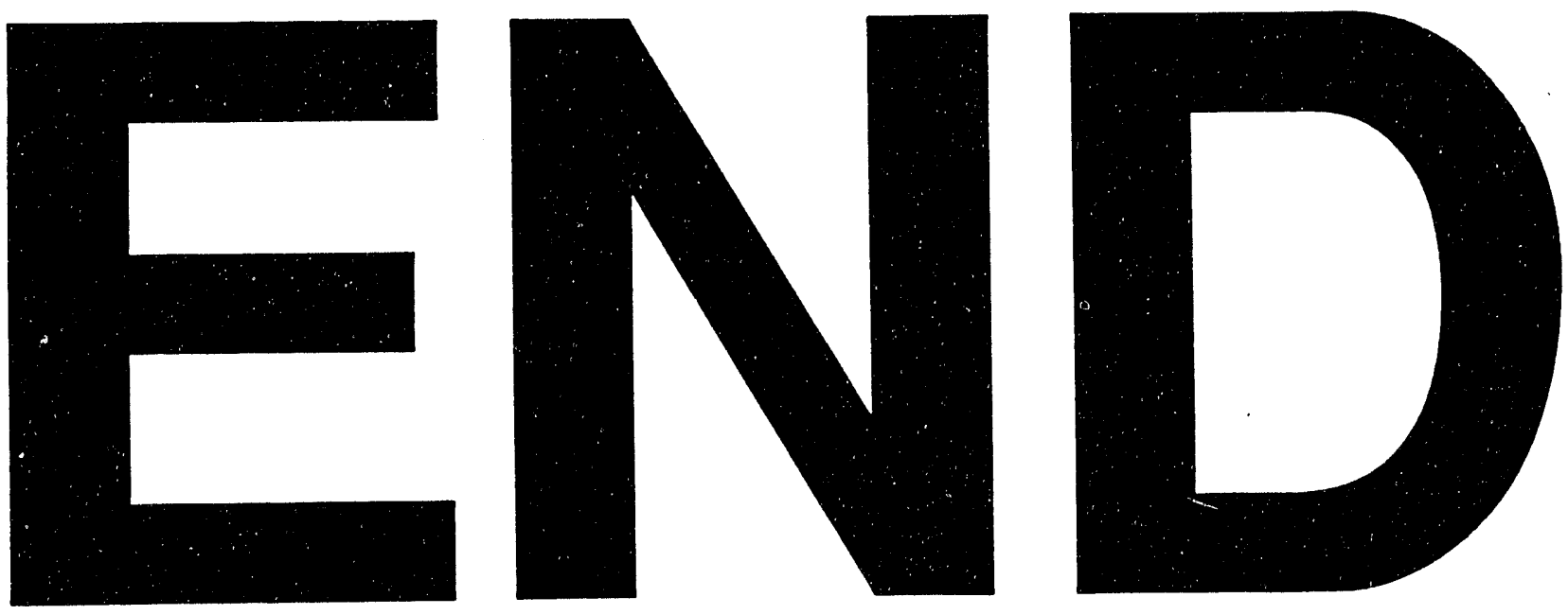